\title{
Did Structured Credit Fuel the LBO Boom?*
}

\author{
Anil Shivdasani \\ Department of Finance \\ Kenan-Flagler Business School \\ University of North Carolina at Chapel Hill \\ Anil.Shivdasani@unc.edu \\ Yihui Wang \\ Department of Finance \\ Kenan-Flagler Business School \\ University of North Carolina at Chapel Hill \\ Yihui_Wang@unc.edu
}

April 24, 2009

\begin{abstract}
We demonstrate a link between the twin storms underlying the current financial crisis - the market for collateralized debt obligations (CDOs) and the market for leveraged loans. We show that structural changes in credit markets that led to the explosion in CDOs created an increased supply of bank loans for funding LBOs. This structured lending supported by CDOs led to cheaper credit, looser covenants, and more aggressive use of bank loans in financing LBOs. However, in sharp contrast to the LBO boom in the late 1980s, this easy credit did not lead to riskier LBO deals or deal structures. Our findings point to the effects of disintermediation of banks as they switched from an originate-and-hold to an originate-to-distribute lending model.
\end{abstract}

Keywords: structured credit, credit supply, leveraged buyout, collateralized debt obligation, loan sales, bank monitoring

JEL Classifications: G31, G32, G34

\footnotetext{
* We thank Greg Brown, Matthias Kahl, Wayne Landsman, Paige Ouimet, Chris Parsons, Adam Reed, Jay Ritter, Ed Van Wesep, and seminar participants at American University, Chinese University of Hong Kong, City University of Hong Kong, Hong Kong Baptist University, Nanyang Technological University, Southern Methodist University, Texas Christian University, Tsinghua University, University of Florida, University of North Carolina, University of Oregon, and University of Wisconsin at Madison for helpful comments. We thank Chris Flanagan and Kedran Panageas of JP Morgan and Marc Auerbach of S\&P for helpful discussions. We thank Asset-Backed Alert for sharing their data and updating the sample to include recent deals. An earlier version of this paper was titled “Does Credit Supply Drive the LBO Market?”.
} 


\section{Introduction}

The past few years have witnessed a dramatic boom and the bust of highly levered transactions such as leveraged buyouts (LBOs). From 2004 to 2007, \$535 billion of public-to-private LBOs were completed, more than ten times the $\$ 50$ billion of LBO volume over the combined previous eight years from 1996 to 2003 (Figure 1). This recent LBO boom eclipses the 1986-1989 boom where completed LBO volume reached $\$ 137$ billion. The collapse of the recent LBO boom was as dramatic as its rise, with LBO volume dropping by $94 \%$ in the fourth quarter of 2007 from prior year levels.

This enormous rise and spectacular collapse cannot be explained by trade-off theories of capital structure. In the trade-off framework, LBOs are thought of as creating value by increasing interest tax shields or lowering agency costs. However, these benefits are unlikely to vary as sharply over time as observed LBO volumes. In this paper, we examine the role of the supply and pricing of credit from structured credit markets to understand their effects on LBO transactions. The LBO boom coincides with important developments in the structured credit markets that substantially increased the supply of credit. We argue that these developments, notably the expansion of the market for collateralized debt obligations (CDOs), had a substantial impact on the LBO transactions and how these transactions were funded. As investor demand for CDOs increased, CDO issuers needed more collateral assets to issue CDOs, providing banks with incentives to originate loans used to fund LBOs that could be placed in CDO vehicles. We argue that this easier access to credit led to more highly levered transactions such as LBOs and increased the amount of debt used in these transactions. We suggest that these forces led to the increased frequency of LBOs and to larger loans provided to support these transactions.

We consider several questions arising from these credit market developments. How did the growth of the CDO market affect banks' lending policies? Did the ability for banks to sell loans through CDO distribution channels lower their screening incentives and lead to more loans to lower quality issuers? How did this increased availability of credit affect the incentives of management and financial sponsors that structured the LBO transactions? Did the easier access to credit lead to riskier LBO deals? 
The goal of this paper is to examine how developments in credit markets affect the supply of credit and their impact on corporate investment and capital structure decisions. Much of the literature has focused on demand-side firm characteristics related to taxes, agency problems, information asymmetry, and bankruptcy costs to understand these decisions, but less is known about the role of supply-side factors. Recent papers by Faulkender and Petersen (2006), Sufi (2009), and Lemmon and Roberts (2008) examine supply-side effects in capital structure decisions. We extend this literature by studying the role of supply-side effects on the M\&A market, the structure of transactions, and the attributes of deals. The LBO market is well suited to study these issues because the extensive use of debt in these transactions makes it very sensitive to changes in credit supply.

Our paper highlights the intricate link between two markets at the heart of the recent financial crisis. Losses on CDO positions and from leveraged loans have been a primary source of asset write-downs for most large financial institutions as valuations for both of these types of securities have plummeted and their secondary markets have remained essentially frozen. Though CDOs originally involved collateral assets such as loans held on balance sheets of financial institutions and corporate bonds, the market expanded in recent years to include CDOs backed by structured products and arbitrage collateralized loan obligations (CLOs) used to exploit yield differentials between underlying assets and funding costs. Bank loans used to finance LBOs were often placed in these CLO vehicles. The CDO channel vastly increased the supply of credit by expanding the base of investors to include not only banks but also hedge funds, insurance companies, pension funds, and others, because it allowed these investors to diversify their positions by holding a pool of assets and by allowing them to choose to invest in tranches most suited for their risk preferences. The CDO channel also allowed banks to lend more because they became less constrained by their balance sheets since they no longer needed to meet capital requirements when the loans were sold to CDOs. In fact, underwriting CDOs was typically a profitable activity for many large lending banks. Finally, the CDO technology made it possible to issue investment-grade securities backed by a pool of assets with lower ratings, thereby breaking market segmentation and bringing in the much larger capacity of investment-grade markets to the leveraged loan market. For these reasons, CDO 
issuance exploded during the same time period as the recent LBO boom. Aggregate CDO issuance rose to \$1.3 trillion over 2004-2007, twice the total issuance volume over the previous eight years (Figure 1), but it also dropped sharply in the second half of 2007.

The simultaneous explosion in the CDO and LBO markets makes it complicated to disentangle causality. Under the CDO driven supply story, the availability of credit through the CDO market allowed banks to become more aggressive lenders for LBO loans. However, an alternative view is that growth of the CDO market was LBO-driven. This could arise if an increase in the demand for LBOs transactions, perhaps due to increased agency costs, greater expected tax shields, etc., created the demand for more bank loans, leading the banks to create CLO vehicles where these loans were sold to investors. Yet another interpretation is that the growth of both the LBO and CDO markets occurred simultaneously because of some unobserved factor.

To differentiate between these interpretations, we adopt several strategies. The first strategy is to employ variables that are correlated with the supply of credit from the CDO market but are unlikely to be affected by the demand for LBOs. We develop these measures by exploiting the variation in the type of CDO structures. The first set of measures is based on the non-CLO CDOs, which typically represent structured product CDOs. Backed by securitized assets ${ }^{1}$, structured product CDOs are unlikely to be affected by the demand for LBOs because LBOs do not produce securitized assets that are used to support these issues. The second set of measures exploits more traditional forms of securitization, e.g., mortgagebacked securities (MBS) and asset-backed securities (ABS). Collateral assets of MBS and ABS include residential mortgages, home-equity loans, credit card loans, auto loans, and student loans. These assets are not likely to be driven by the demand for LBOs. Yet, as ancestors of CDOs, these two markets are highly correlated with the CDO market.

One of our primary results is to demonstrate a strong link between these non-LBO-driven CDO structures and overall LBO volumes. Supporting the notion that the increase in the supply of credit

\footnotetext{
${ }^{1}$ Such assets include residential mortgage-backed securities, commercial mortgage-backed securities, collateralized mortgage obligations, asset-backed securities, and other securitized assets, even other CDOs.
} 
through structured credit markets facilitated LBOs, we show that our CDO variables display a correlation ranging from 0.57 to 0.95 with LBO volume. The correlations remain very high when we control for other variables related to the demand for LBOs and other sources of credit supply.

Our second strategy to differentiate between CDO-supply and LBO-demand effects is to examine the correlation between the changes in the price of credit and changes in the aggregate volume of LBO loans. In equilibrium, a positive demand shock should drive up both price and quantity, leading to a positive correlation between the changes in price and quantity. However, a positive supply shock should depress price while driving up quantity, generating a negative correlation between the changes in price and quantity. Empirically, we document a strong negative correlation between the changes in LBO loan volumes and the changes in credit spreads of tranches in which CLO vehicles invest, supporting the view that positive shocks in the supply of credit drove the LBO boom.

To test whether unobserved factors drove the link between the CDO and LBO markets, we look for direct evidence on how the CDO driven increase in credit supply affected banks' lending decisions. We show that LBO lending increased the most for banks that had CDO underwriting capabilities which allowed them to tap into this increased credit supply. In fact, all the top ten lead banks extending LBO loans after 2004 were also all top CDO underwriters. In a bank fixed-effects model, we find a positive within-bank correlation between a bank's LBO lending and its access to the CDO capital. Specifically, our results show that in years when a bank underwrote more non-CLO CDOs, it also originated a larger amount of loans to finance LBOs.

To further test the idea that the CDO market increased the supply of credit for LBOs, we examine how LBO loans were financed in the syndicated loan market and explore whether CLO vehicles financed a substantial portion of these loans. Using data on the tranche structure of the LBO loans, we identify the allocation to all institutional investors, among which CLO vehicles were the primary investor and have become more important over time. During the LBO boom years (2004-2007), the institutional tranches accounted for $60 \%$ of the loan amounts, compared to $44 \%$ in the pre-boom years. Further, lead banks that were more active in CDO underwriting also allocated more of their LBO loans to institutional investors. 
This suggests that better access to CDO investors allowed banks to raise more capital from this market to finance their loan commitments for LBOs and establishes a direct link between the CDO and LBO markets.

The CDO channel also had substantial impacts on the cost of credit of LBO loans. We show that banks with larger CDO underwriting businesses offered cheaper credit and with looser covenant protection to LBOs and transactions involving these banks employed bank loans more aggressively. A one standard deviation increase in the relative size of CDO funding of the lead bank implies that the loan spread decreases by 17 to 20 basis points, the probability of having a covenant-lite tranche increases by $5 \%$ to $12 \%$, and the total amount of non-contingent bank loans (e.g., non-revolvers) in the capital structure of the LBO deal increases by an amount equal to 70\% of the EBIT of the LBO target firm. Thus, CDOs facilitated easier credit terms for LBO financing.

Our results highlight an important shift that occurred in the lending model of banks in recent years. Banks appear to have moved from a deposit-based funding model to a structured lending model where they obtained their financing from structured credit, such as CDOs. Upon originating loans, banks sold them to CDO vehicles instead of holding them on their balance sheets. This approach has the potential to fundamentally alter banks’ role in information production, monitoring, and enforcing contracts (Diamond (1984, 1991), Rajan (1992)), because they may no longer bear the costs of risk-shifting by borrowers (Jensen and Meckling (1976)). Indeed, Pennacchi (1988) and Gorton and Pennacchi (1995) have suggested that incentives of banks to monitor are reduced as their funding gets outsourced to capital markets. Thus, an important issue is the effect of disintermediation of banks as they switch from an originate-and-hold to an originate-to-distribute model and whether this switch affected the quality of their loan decisions.

Did structured credit lead to worse LBO deals? We show that the target firms in the CDO-driven deals generated more free cash flows, paid more taxes, and were less risky. By most conventional measures these were good LBO candidates, in sharp contrast to the LBO deals that occurred during the prior LBO boom in the late 1980s. One explanation for this difference in findings between these two LBO 
booms is that in our sample, the CDO-driven LBOs were much larger firms - typically four times the size of non-CDO led LBOs. Thus, a primary impact of the CDO credit channel was to facilitate much larger LBOs than historically possible, offering an explanation for why nine of the ten largest LBOs were announced during 2006 and 2007. This suggests that the CDO-driven credit supply relaxed financing constraints for large LBOs rather than facilitating worse quality deals.

Even if the target firms were not more risky, deals can still be structured to assume more risk by employing a capital structure with more debt and less equity. We do not find evidence that this was the case. While CDO-driven deals borrowed more from banks, equity contributions in the deals were not reduced. In fact, these deals appear to arrange more financing than needed to complete the deal, possibly resulting in more flexibility in arranging the final deal structure. When we consider LBO premiums, we do not find evidence indicating overpayment in the CDO-driven deals. Overall, these results suggest that banks retained their incentives to screen borrowers when originating LBO loans even when the loans were sold to CLOs, possibly because of incentives to preserve reputation as diligent underwriters.

Our paper contributes to several areas of research. It adds to a growing body of literature including Faulkender and Petersen (2006), Sufi (2009), Leary (2005), and Lemmon and Roberts (2008), on how the supply of credit affects firms' financing and investment decisions. Unlike these papers, we focus on LBO transactions, which involve extensive leverage. Our findings suggest that the importance of supply side factors can be substantial. We also add to the emerging inquiry on how securitization affects the behavior of lenders and users of credit. Mian and Sufi (2008) suggest that the increase in the supply of credit due to securitization contributed to the growth of the subprime mortgage market and its subsequent collapse. Loutskina and Strahan (2009) show that the ability to securitize mortgage loans increased the willingness of banks to increase their mortgage lending. To our knowledge, ours is the first study on the effect of securitization markets on corporate lending behavior.

The paper contributes to the literature on LBOs and suggests that LBO booms are not necessarily associated with lower quality transactions. Kaplan and Stein (1993) show that the LBO market in the late 1980s was overheated and argue that the capital from junk bond investors contributed to this overheating. 
Unlike high-yield bonds, loans sold to CDOs were originated by banks, which may have resulted in stronger incentives for banks to screen borrower quality. Our evidence adds to other contemporaneous investigations of the pricing and structure in the recent LBO boom. Demiroglu and James (2007) and Ivashina and Kovner (2008) also look at LBO loans in the recent years, but focus on the reputation of private equity groups and their relationship with lenders. Other studies exploring related issues include Acharya and Johnson (2008), Axelson et al. (2008), Boone and Mulherin (2008), Guo et al. (2007), Kaplan and Stromberg (2009), Metrick and Yasuda (2008), and Officer et al. (2008).

Finally, the paper adds to the literature on loan sales, including Drucker and Puri (2007), Parlour and Plantin (2008), Guner (2006), and Gande and Saunders (2006). While both structured lending supported by CDOs and loan sales allow banks to expand their lending capacity, the two mechanisms have important differences. By pooling and tranching, the CDO technology introduces a broader base of nonbank investors to bank loans. Further, buyers in the loan sales market have the incentive, and potentially the expertise, to monitor borrowers since they bear the costs of risk-shifting by the firm. In contrast, CDO investors, because they are diversified by virtue of holding only one slice of each loan in collateral pools, lack the incentive or the expertise to monitor.

The paper proceeds as follows. Section I describes the markets for CDOs and leveraged loans in more detail. Section II describes the sample and the data. Section III discusses the empirical methodology. The results are presented in Section IV. Section V examines the effects of CDO lending on the structure and pricing of recent LBO transactions. Section VI concludes.

\section{Background: Collateralized Debt Obligations and Leveraged Loans}

\section{A. Collateralized Debt Obligations}

Collateralized debt obligations (CDOs) refer to notes issued by a special-purpose vehicle (SPV) which are collateralized by a portfolio of assets acquired by the SPV. The SPV is often referred to as the CDO vehicle. For a CDO vehicle, the CDOs, the issued notes, represent its liabilities, while the securities or assets it acquires to back the notes are its assets. Depending on the underlying assets, CDOs can be categorized into collateralized loan obligations (CLOs), collateralized bond obligations (CBOs), or 
structured product CDOs. ${ }^{2}$ The liabilities of CDO vehicles are divided into tranches with differing levels of seniority, and hence, risk. Equity tranches absorb the first loss, followed by mezzanine tranches, and then, senior (and in some cases, super senior) tranches. The capital structure of a typical CDO consists of roughly $10 \%$ equity, $20 \%$ mezzanine, and $70 \%$ senior tranches, but can vary based on the collateral assets. $^{3}$ Senior tranches are commonly rated at investment-grade with the majority at AAA, even though the collateral assets may be rated much lower. Techniques such as over-collateralization, and the purchase of credit and/or liquidity enhancements are commonly employed to achieve the higher ratings for the senior tranches. ${ }^{4}$ Fitch Ratings (2007) notes that almost $60 \%$ of the structured finance notes they rated received an AAA rating.

The CDO technology, by combining the benefits of diversification of the collateral pool and riskreturn tailoring provided by the tranches, attracts a broad base of investors including banks, hedge funds, insurance companies, pension funds, and asset managers. Asset managers manage the portfolio of CDO vehicles and receive fees. They commonly also hold the equity tranche to reduce agency problems between the manager and investors. ${ }^{5}$ Hedge funds are also large buyers of the equity tranche, although they invest in other tranches as well. Insurance companies more commonly invest in the mezzanine tranches, while banks tend to be major investors in senior tranches. The very high credit ratings of the senior tranches make them attractive investments for banks because they impose a low capital requirement under risk-based capital standards. All of these different investors actively invest in CLOs. For example, about half of the CDOs that insurance companies purchased were CLOs, according to Citi Credit Research (2007). The assets of these CLO vehicles are primarily leveraged loans which are

\footnotetext{
${ }^{2}$ In cash CDOs the vehicle acquires the underlying assets, while in synthetic CDOs the vehicle usually does not acquire the assets but only the risk associated with them through credit default swaps.

${ }^{3}$ For example, $60 \%$ of the capital structure of CLOs consists of senior tranches, while senior tranches comprise about $80 \%$ of the capital structure of high-grade structured product CDOs (Citi Credit Research (2007)).

${ }^{4}$ See Coval et al. (2008b) for a discussion on how such high ratings are achieved given the much riskier collateral assets in CDOs and what went wrong in the CDO market in recent years.

${ }^{5}$ Garrison (2005) argues that keeping the equity tranche is more efficient than other contracts based on debt and fees in solving the agency problem between CDO managers and CDO investors. Franke and Herrmann (2007) provide evidence that managers hold more of the equity tranche when collateral quality is lower.
} 
commonly used to finance LBOs. According to the Securities Industry and Financial Markets Association (SIFMA), all of the CLOs issued between 2005 and 2007 were backed by leveraged loans. Thus, CLOs help bring a wide range of investors to the leveraged loan market.

CDOs can be classified into two types. Balance sheet CDOs are issued for the purpose of removing existing assets (or the risk of assets) from the balance sheet of the seller. For example, an automotive finance company might wish to free up balance sheet capacity for funding new auto loans, and can do so by a creating a balance sheet CDO to transfer their existing auto loans to CDO investors. Since balance sheet CDOs are issued only to remove assets already on the issuer's balance sheet, issuance volume in this market is not driven by the origination of new loans that would not be held on the issuer's balance sheet.

In contrast to balance sheet CDOs, arbitrage CDOs are created in an attempt to capture a mismatch between the yield of CDO collateral and the financing cost of CDO tranches. In arbitrage CDOs, issuers (usually asset managers and hedge funds) typically do not have the underlying assets and need to purchase them in the marketplace. Thus, arbitrage CDOs, particularly arbitrage CLOs, create incremental demand for leveraged loans, and encourage the supply of additional credit to leveraged borrowers. According to SIFMA, 87\% of CDOs created between 2004 and 2007 were arbitrage CDOs. The growth in the popularity of arbitrage CDOs suggests that the CDO-driven demand for holding credit exposure created incremental supply of credit to highly leveraged transactions because banks could sell these loans to arbitrage CDOs without holding them on their balance sheet. In these transactions, it is common for banks to participate as underwriters in the CDO issuance. It is worth noting that demand for collateral assets arises not just at the creation of the CDO but can extend beyond the initial CDO issuance. According to Barclays (2002), underlying assets can be purchased in multiple stages, starting before the issue and continuing up to six months after. In addition, once a CDO is created, cash flows from principal repayments resulting from amortization, maturity, prepayment or asset sales are usually reinvested, generating continual demand for collateral, including LBO loans. 
The CDO market has a long history, but increased sharply in importance in recent years. The first CDO was issued in 1987, but the market remained very small until 1996 (Kothari (2006)). From 1998 to 2003, CDO issuance amounts remained stable at about $\$ 80$ billion per year. Starting in 2004, the CDO market experienced explosive growth, when a total value of \$127 billion CDOs was issued. This amount quadrupled in only two years (Figure 1). The annual growth rate in this market in 2004, 2005, and 2006 was $61 \%, 100 \%$, and $90 \%$, respectively.

Although there are many reasons for this dramatic growth, a potentially important driver was the change in incentives of banks regarding securitization resulting from the Basel II Accord, first published in June $2004{ }^{6}$ This regulation was intended to reflect the risk of assets on banks' balance sheets and discourage regulatory arbitrage under the Basel I Accord by assigning low weights to highly-rated assets and high weights to lower-rated assets in calculating required capital. ${ }^{7}$ This requirement thus encouraged banks to remove risky assets from the balance sheet (which imposed a high capital charge) and transform them to highly-rated assets (which required less capital). The CDO technology was a particularly effective way to enable this transformation of the balance sheet and free up capital. The CDO market allowed banks to sell risky assets with high capital requirement, such as leveraged loans, to CDO investors, while at the same time investing in the senior CDO tranches which required less capital. ${ }^{8}$ The incentive of banks to hold senior tranches was a critical element in the expansion of the CDO market because most of the other major CDO investors (e.g., hedge funds and insurance companies) were more

\footnotetext{
${ }^{6}$ Though Basel II has not been uniformly implemented in U.S., JP Morgan (2007) argues that that the effects of its implementation were clearly anticipated in market prices. During this period, most large "internationally active" banks moved towards a risk-based capital approach both for their internal capital management as well as for communicating their capital positions to analysts and investors.

${ }^{7}$ Basel I provided a very coarse classification of risk, lumping bank assets with very different characteristics into similar risk buckets for purposes of calculating capital requirements. This gave banks incentives to securitize their high quality assets while keeping risky assets on their balance sheet, since risky assets earn higher expected returns. Basel II was designed, to a large extent, to prevent an increase in risk in the banking system produced by this regulatory arbitrage.

${ }^{8}$ According to JP Morgan (2007), the weight on some AAA investment in securitized assets is only $7 \%$. With an $8 \%$ capital requirement, an investment in a AAA security requires banks to put only $0.56 \%$ (7\% x 8\%) of capital, an implicit leverage of 178 times (1/0.56\%). JP Morgan notes that "the Basel II capital framework for securitization was a key driver of the excessive leverage applied to ABS securities via structured finance CDOs.”
} 
interested in junior tranches that offered a higher risk-return proposition. This reasoning suggests that the explosion in the CDO market and the move towards risk-based capital management advocated by Basel II is not coincidental. However, to the extent that the higher ratings of the tranches did not accurately anticipate the inherent risk of the underlying collateral, banks may have ended up holding less capital than needed against these investments. Giaccherini and Pepe (2008) argue that a rating-based approach in calculating capital requirement does not fully cover the economic risk of CDO tranches held on banks' balance sheets. They conclude that "it should be questioned whether the Basel II mapping from ratings to capital is the right choice or is it encouraging new forms of arbitrage”.

The CDO market collapsed in the summer of 2007 as escalating subprime mortgage defaults wiped out the equity and mezzanine tranches and inflicted heavy losses on the senior tranches as well. Overall CDO issuance has shrunk substantially since then. While the market for structured-product CDOs virtually disappeared in 2008, CLOs continued to exist, though issuance volume dropped by $70 \%$ in the first half of 2008 from a year earlier. Figure 2 plots the spreads of AAA-rated tranches of CDOs collateralized on high-yield loans, high-grade and mezzanine structured products. When structured credit markets collapsed in April 2008, spreads on the highest-rated CDO tranches backed by mezzanine structured products experienced an dramatic spike, from about 30 basis points in early 2007 to about 1,450 basis points. However, the spread on the similarly rated CDOs backed by high-yield loans increased to only 175 basis points. Thus, the turmoil in structured credit markets does not appear attributable to concerns over LBO loans. Instead, this data suggest that investor concerns surfaced with structured product CDOs and the increased risk aversion in these markets spread to the CLO markets used to finance LBO loans.

\section{B. Leveraged Loans}

Leveraged loans, or high-yield loans, are bank loans issued to borrowers with speculative-grade ratings. Many of the large leveraged loans, particularly LBO loans, are syndicated. The volume of syndicated leveraged loans more than tripled from \$218 billion in 2001 to \$689 billion in 2007, exceeding for the first time, the volume of syndicated investment-grade loans. In the syndicated loan market, 
investors can be classified into pro rata investors and institutional investors. According to S\&P (2006), banks and finance companies are pro rata investors and typically invest in pro rata tranches, which include the revolver and term loan A (or amortizing term loan) tranches. CLO vehicles, prime funds, hedge funds, and insurance companies typically comprise the bulk of the institutional investors. These investors invest in institutional tranches, which include the term loan B, C, and D tranches. These term loans are bullet payments and lie below the term loan A tranche in seniority. Thus, institutional tranches are priced with higher spreads than the pro rata tranches. ${ }^{9}$ Since CLO vehicles are institutional investors, our analysis focuses on the pricing of the institutional tranches, usually measured by spreads on the term loan $\mathrm{B}$, the most common institutional tranche.

Institutional investors have become increasingly important in the syndicated loan market. According to Loan Pricing Corporation (LPC), the share of institutional tranche (term loan B only) in syndicated loans increased from $30 \%$ in 1996 , to $43 \%$ in 2001 , to $75 \%$ in $2007 .{ }^{10}$ In the institutional market, CLO vehicles are one of the major investors, representing $60 \%$ of the institutional investors in 2006, according to S\&P (2006). This increasing share of CLO vehicles among the institutional investor base implies that a substantial part of the financing of leveraged loans came from CLO vehicles. Consistent with this view, Figure 3 displays a close linkage between new CLO issuance volumes and the allocation of leveraged loans to institutional tranches. As suggested by the preceding discussion, Figure 3 also shows that CLO issuance volumes are much less closely linked to the pro rata investor allocations of leveraged loans.

Another recent phenomenon in the leveraged loan market has been the emergence of covenant-lite loans. Covenant-lite loans have only incurrence covenants (which are met at the initiation of the loan), but none of the traditional maintenance covenants that require borrowers to maintain financial ratios at prespecified levels at the end of every quarter. Without maintenance covenants, lenders need to rely solely on

\footnotetext{
${ }^{9}$ After 2001, spreads on an increasing number of institutional tranches were priced closer to pro rata tranches, and in some cases were even lower despite their lower seniority according to S\&P (2006), which attributes this to the higher demand for leveraged loans from institutional investors.

${ }^{10}$ The increasing share of institutional investors over time has had the effect of squeezing out the term loan A tranche and more recent deals were commonly structured with only a revolver and a term loan B tranche.
} 
incurrence covenants, that are breeched only when a particular action (e.g., paying a dividend, issuing more debt, or making an acquisition) triggers the failure to meet certain financial requirements. Hence, covenant-lite loans are much less stringent on borrowers than traditional bank loans. According to S\&P’s Leveraged Commentary \& Data (LCD) (2007), outstanding covenant-lite loans accounted for less than $1 \%$ of leveraged loans before 2005, increased to almost $5 \%$ in 2006 , and jumped to $18 \%$ in the first half of 2007. S\&P (2006) notes that covenant-lite loans "thrive only in the hottest markets when the supply/demand equation is tilted persuasively in favor of issuers”. All else equal, a covenant-lite loan provides the borrower with much greater flexibility and represents a cheaper source of financing than a regular loan with maintenance covenants. Since pricing and covenant restrictions represent two sides of the same coin, we also study how supply effects from structured credit markets affected the extension of covenant-lite loans.

\section{Data and Sample Description}

\section{A. The LBO Sample}

Our sample of LBOs is from SDC Platinum and consists of 345 deals satisfying the following criteria: the transaction was announced between 1996 and the second quarter of 2008 and completed by the end of July 2008; the target is a publicly traded U.S. company; the transaction value is at least \$10 million; at least $50 \%$ of the common shares were acquired in the deal and the buyers owned $100 \%$ of the shares upon completion. Our minimum deal value of $\$ 10$ million is lower than that in some other studies, such as Kaplan (1989b) and Guo et al. (2007), and chosen to avoid biasing against earlier time periods when smaller deals were more common.

Figure 1 shows the distribution of LBOs by when they were announced. The LBO boom from 2004 to 2007 clearly stands out. Quarterly LBO volume never exceeded \$5 billion until the second quarter of 2004, when $\$ 5.6$ billion of LBOs were announced. The pace of LBOs picked up dramatically, reaching $\$ 20$ billion in the last quarter of 2005. A year later, LBO volume reached \$106 billion in the fourth quarter of 2006. At \$255 billion of announced deal volume, 2006 was a record year for LBOs. With the onset of the credit turmoil in the summer of 2007, LBO volume dropped to $\$ 32$ billion in the third quarter 
of 2007 and to under $\$ 5$ billion in the first quarter of 2008. The number of deals also increased during 2004-2007 but much less dramatically because much larger LBO deal sizes were a hallmark of the boom.

We collect detailed data on the loan structure of the 345 deals in our sample using LPC's DealScan and manually collected information from proxy filings. We match the LBO targets with LBO loans from DealScan and collect data on tranche types and amounts, lead arrangers, spreads, maturity, and other terms. We also manually check proxy filings as well as schedules 14A, TO-T, S-4 and 13E3 when these filings are available in Edgar. For loans not in DealScan, we collect information on lead banks, tranche types, amounts, spreads, and maturity whenever available. For deals in DealScan, we use information in proxy filings to remove tranches that can be identified as asset-backed financing. ${ }^{11}$ Asset backed loans are excluded to avoid potential bias resulting from securitized financing other than CDOs. ${ }^{12}$

We are able to collect LBO loan details for 275 loans financing 241 deals (70\% of the sample), for which lead arrangers and borrowing amounts are available. We lose some firms because several small deals are funded by cash, mezzanine finance, or equity and do not arrange bank loans to finance the deal. Some deals are not conditioned on the availability of financing and thus lack disclosure on loans, a few loans classified as asset-backed are excluded, and for some firms, filings are unavailable on Edgar. After constructing the loan sample, we identify covenant-lite tranches for each loan using data from S\&P's LCD.

Figure 4 shows the volume of bank loans in each quarter. The pattern mirrors the volume of LBO transactions, with heavy volume between the second quarter of 2004 to the first half of 2007. Total bank borrowing peaks in the second quarter of 2007, while LBO volume peaks at the end of 2006. This is because the loan sample excludes the commercial mortgage financing for a few large deals announced in the fourth quarter of 2006, including the $\$ 41$ billion LBO of Equity Office Properties, and the \$28 billion

\footnotetext{
${ }^{11}$ For example, commercial mortgage-backed financings were used in the buyouts of UICI, La Quinta, and Station Casinos, but these are included in DealScan as "other loan" tranches.

${ }^{12}$ When DealScan and proxy filings differ, we retain the DealScan information since terms specified in proxy filings are sometimes adjusted after the filing and hence may not be the final terms.
} 
buyout of Harrah's Entertainment. On average, bank loans comprise 53\% of the LBO volume during the sample period.

We also identify the complete financing structure for 235 (68.1\%) of the sample deals. We collect this information from proxy filings, supplemented with SDC's data on high yield bond issuance. We record the total funding needed to complete the deal and the amounts of total equity financing including from rollover investors, asset-backed financing, high yield bonds/notes, and mezzanine finance when available. $^{13}$

\section{B. Data for CDO and Other Securitized Issues}

Data on CDOs and other securitized issues are from the ABS Database of Asset-Backed Alert which provides the initial terms of all rated issues of ABS, MBS, and CDOs worldwide. ${ }^{14}$ The first full year of CDO coverage begins in 1996 and hence we use this as the starting point in analyses involving CDO data.

From 1996 to the second quarter of 2008, 4,542 CDOs with a total value of \$1.9 trillion were issued. Figure 1 shows that CDO volume exploded at the same time as the LBO boom. Quarterly CDO issuance volume in the pre-LBO boom period of 1996-2003 averaged \$19 billion, which doubled in the third quarter of 2004 immediately after publication of the Basel II Accord. Annual issuance amount subsequently doubled in the following two years, reaching almost $\$ 160$ billion by the end of 2006. The market started to shrink significantly in the third quarter of 2007, coincident with the rise in subprime mortgage defaults. Figure 1 shows the virtually identical trajectories in the LBO and CDO markets with both markets rising and falling at the same time. The correlation of between quarterly LBO volumes and CDO issuance amounts is almost perfect at 0.94 .

\footnotetext{
${ }^{13}$ Total funding needs include cash needed to pay off equity, option and warrant holders, retire existing debt, and pay for fees and expenses related to the deal. The amount of bank financing is from the bank loan data. When a deal cannot be matched with a bank loan in the loan sample, and the proxy filings indicate no bank financing, bank financing is assumed to be zero. Bridge loans or other bridge financing are recorded as high yield bond/note and mezzanine finance. The amount of high yield bond issues is supplemented by bond issuance data in SDC for 40 deals where the hand collected amounts are different from proceeds recorded in SDC. Equity contributions and asset-backed financing are from proxy filings.

${ }^{14}$ To be included in the ABS database, an issue must be rated by at least one major rating agency, under control of a trustee, and collateralized on some assets. It excludes commercial mortgage-backed issues, agency sponsored MBS, issues by municipalities, tax-exempt issues, and asset-backed commercial paper issues.
} 
Table 1 summarizes the size and the structure of the structured credit markets and illustrates how the market changed from the pre-2004 (1996 to 2003) to post-2004 (2004 to the first half of 2008) period. Panel A summarizes the CDO market. We have detailed data on the underlying collateral for CDOs after 2001, while before 2001 we are only able to differentiate between balance sheet CLOs from other CDOs. Hence, Panel A compares CDO issuance during 2001-2003 to the post-2004 period. The CDO market witnessed explosive growth during this period, rising from aggregate issuance volume of \$255 billion to over $\$ 1.3$ trillion. The majority of these CDOs were backed by three types of collateral: structured products, corporate loans, and corporate bonds and there are sharp differences in how these different CDO products grew in the post-2004 era. During 2001-2003, there were 252 structured product CDOs with an aggregate issuance volume of $\$ 63.9$ billion, but this market grew to 1,243 issues at total value of \$556 billion in the post-2004 period. The growth in arbitrage CLOs was even more striking. With 153 issues representing $\$ 46.9$ billion of issuance in the 2001-2003 period, arbitrage CLOs grew almost sixfold in the number of issues, and nine-fold in issuance volume in the post-2004 period. The sharp growth in arbitrage CLOs is particularly relevant since these vehicles served as the conduit by which banks could originate new LBO loans and sell them to structured credit investors without having to place the loans on their balance sheet.

Other categories of CDOs related to LBO financing show much less dramatic growth, and even some contraction. Of particular interest are balance sheet CLOs that hold leveraged loans previously held on originators' balance sheets. Issuance in this market actually dropped from 90 to 76, but volumes rose from $\$ 41.6$ billion to $\$ 75.6$ billion in the post-2004 period. Also of interest are the high yield CBOs which could invest in the junk bond issues that were used to finance LBOs in the public high yield markets. This market contracted from 72 issues to 37 issues, with issuance volume dropping from \$24 billion to \$12.6 billion in the post-2004 period. Thus, the growth in arbitrage CLOs was much larger than other LBO financing related vehicles such as balance sheet CLOs or CBOs.

Panel B of Table 1 summarizes the size of the entire structured credit market. The total volume of securitized issues rose from $\$ 4.76$ trillion during the eight years from 1996 to 2003, to $\$ 8.07$ trillion over 
the next four and half years. The bulk of the growth arises from expansion of the CDO market and of structured credit linked to U.S. and non-U.S. residential real estate. Total CDO issuance more than doubled during this period, total U.S. MBS issuance almost tripled, and U.S. home equity loan ABS issuance along with non-U.S. residential MBS/ABS issuance more than doubled. The growth in the CDO market more closely parallels the growth in the MBS market, whereas the ABS market grew at a slower pace and dropped in market share from $43.9 \%$ to $30.5 \%$. Thus, changes in the ABS market are expected to be a weaker proxy for the shift in supply of credit in the CDO market than the changes in the MBS market.

\section{Identification and Empirical Strategies}

We postulate that the expansion of the CDO market contributed to the recent LBO boom. We argue that the ability to sell leveraged loans to CDO vehicles led banks to extend more loans to fund LBOs. However, the tight correlation between the LBO and CDO markets is equally consistent with an alternative view. Under this alternative, demand for LBOs increased for reasons unrelated to the CDO market. To accommodate the increased demand, banks lent more to finance LBOs, resulting in large balance sheet exposure to leveraged loans. These exposures were then reduced by selling these loans to CDO vehicles, thereby removing them from the banks' balance sheets. This alternative view suggests that the growth in LBOs led to the expansion of the CDO market. This reverse causality arises because of banks' desire to reduce their balance sheet exposures to LBO lending. We employ several empirical strategies to differentiate among these alternatives.

\section{A. Relation of Changes in Prices and Quantities}

To distinguish between a shift in supply for LBO loans and a shift in the corporate demand for LBO loans, our first strategy is to study the correlation of changes in prices and quantity. With a downward sloping demand curve and upward sloped supply curve, an outward shift in demand for LBO loans implies a higher equilibrium quantity and price, generating the prediction of a positive correlation between the changes in prices and quantities. However, an outward shift in supply leads to higher 
equilibrium quantity but lower price, leading to an expected negative correlation between changes in prices and quantities.

Based on the predictions on the direction of price-quantity correlations, we disentangle demand and supply shifts for LBO loans. Our tests treat the new issuance amounts and average spreads in the leveraged loan market as the equilibrium quantity and price in the market for LBO loans.

\section{B. Credit Supply from the Non-CLO Securitized Market}

If expansion in the supply of credit from the CDO market allowed banks to make more LBO loans, we expect that LBO lending should be correlated with all types of CDOs, not just the CLOs that hold leveraged loans. In other words, the size of the non-CLO CDO markets should serve as a measure of the availability of credit in the CDO market because these markets share a common investor base with CLOs. Under the LBO demand view, where the desire of sponsors and management to complete LBOs results in new bank loans that are later sold to CLOs, LBO loan volumes should be correlated with CLO volumes, but not with volumes of non-CLO CDOs.

Thus, our empirical setting treats an increase in volumes of other (non-CLO) CDOs or other types of securitized issues as measures of a shift in supply of credit to LBOs but not in underlying demand for LBO loans. Our first measure relies on the variation in CLO structures. As previously discussed, balance sheet CLOs are affected by the demand for LBOs loans since they are created to remove collateral from the issuers' balance sheets. Thus, balance sheet CLO issuance is most likely to be directly affected by the desire of banks to lower their loan exposures to LBO lending. However, arbitrage CLOs are created to exploit yield differentials between the collateral assets and funding liabilities and are not driven by an intent to lower sellers' exposures to loans. Thus, arbitrage CLO issuance is driven more by the demand by CLO vehicles to invest in leveraged loans and thus represent a source of increased supply of non-bank credit to the LBO market. Therefore, our first measure excludes balance sheet CLOs from the universe of $\mathrm{CDO}$ issues and is referred to as $C D O E x-B S C L O$. Since this measure excludes all CLOs designed to reduce banks' balance sheet exposures to LBO lending, the reverse causality argument suggests this variable should not be linked to LBO volumes. 
LBO financing often entails public debt issuance in high yield markets in addition to leveraged loans. Some of these high yield bonds can also be sold to CBO vehicles which pool and tranche these collateral assets. Thus, CBO issuance volume may be linked to LBO-driven high yield bond issuance, and hence may be affected by LBO demand. Therefore, we employ a second variable that excludes all CLOs (both arbitrage and balance sheet) and CBOs from CDO issuance, and we refer to it as $C D O E x$ CLO/CBO. This variable includes primarily structured product CDOs and CDOs backed by commercial mortgage-backed securities (CMBS) or real estate holdings and excludes all CDO vehicles that may be connected with LBO financing in any way in the leveraged loan or high yield markets. ${ }^{15}$

The last two measures are based on more traditional forms of securitization, i.e., MBS and ABS. The collateral assets in these securitizations include residential mortgages, home-equity loans, auto loans, credit card loans, and student loans. Since LBOs do not create these types of consumer credit, MBS or ABS issuance is not affected by demand for LBOs. Yet as ancestors of CDOs, the MBS and ABS markets are correlated with the CDO market. Therefore, we construct a third measure denoted MBS, which includes all U.S. issued MBS, and a fourth measure ABS, which includes all U.S. issued ABS.

\section{Bank Fixed-Effects Regressions}

We go beyond aggregate level issuance and test specifically whether banks' activities in the CDO markets affected their lending behavior. If increased supply of credit through the CDO market made banks more aggressive LBO lenders, we expect that banks with substantial CDO underwriting activities would originate more LBO loans. With an active CDO market, banks can finance a large part of their loan commitments from CLO vehicles and can sell their share of the loans to CLO vehicles. In many cases, banks also served as underwriters of the CLOs and could generate underwriting fees from the CDO market. These benefits from CDOs encourage banks to lend more to LBOs. This incentive model predicts a positive effect of banks' CDO underwriting on their LBO lending for two reasons. First, underwriting

\footnotetext{
${ }^{15}$ For issues before 2000, only balance sheet CLOs are excluded because the ABS Database does not identify other CLO issues (e.g., arbitrage CLOs) or CBO issues. Potential bias resulting from this should be minor, because the major fluctuations in LBO volume occur after 2000 and because balance sheet CLOs were a large part of the CDO market before 2000, accounting for 34\% of all CDOs.
} 
banks have better access to capital from CDO investors and, hence, are more able to fund their loan commitments. Second, large CDO underwriters have the incentive to create more loans as inputs for their CDO factories to generate more underwriting fees.

To test the effect of banks' CDO underwriting on their LBO lending, we construct a panel dataset to estimate the following bank fixed-effects model:

$$
\text { LBOLending }_{i t}=\sum_{i=1}^{K} \alpha_{i}+\beta * C D O_{i t}+\gamma^{\prime} * X_{i t}+\delta^{\prime} * Z_{t}+\varepsilon_{i t}
$$

where LBOLending $_{i t}$ is the total volume of LBO loans bank $i$ arranges in year $t, \alpha_{i}$ is the bank fixed effect, $X_{i t}$ and $Z_{t}$ are proxies for bank characteristics and macroeconomic conditions, respectively, $C D O_{i t}$ is the volume of CDOs underwritten by bank $i$ in year $t$. We also use our non-LBO linked measures of the $\mathrm{CDO}$ market to proxy for $C D O_{i t}$. If the supply of credit through the $\mathrm{CDO}$ market led banks to be more aggressive lenders, we expect that $\beta>0$.

Using a fixed effects approach allows us to control for unobserved omitted variables. This is important because it is possible that some unobserved factor simultaneously drove both the demand for LBOs and the growth in the CDO market. However, an unobserved omitted factor cannot explain a possible bank level correlation between LBO lending and CDO underwriting.

\section{The Fraction of Loan Financing from Institutional Investors}

A possible omitted variables concern that remains relates to the possibility of time-varying risk aversion of banks. If banks become more risk-tolerant, they may have arranged more LBO loans and at the same time ventured deeper into more risky and innovative activities such as CDO underwriting. If this increase in risk tolerance coincides with the LBO boom, a bank-fixed effects model will not be suited to rule out this time-varying effect. Therefore, to separate this possibility from the CDO-driven credit supply view, we study how the LBO loans are financed in the syndicated loan market. If LBO loan origination is driven by increased supply of credit in the CDO market, one would expect that CDO vehicles would be important investors in the loan. Although we cannot identify each individual investor in a leveraged loan, we are able to measure the proportion of the loan placed in the institutional market where CDO investors 
tend to be the predominant investor group. If CDOs are an important source of credit for leveraged loans, we expect loans led by banks heavily involved in CDO underwriting to have a higher fraction of institutional tranches. In contrast, the time-varying risk argument for the link between LBO loans and CDO underwriting does not have any implications on how the loans are financed.

\section{E. Effect of CDO Capital on LBO Loan Contracts}

For more direct evidence between CDO capital and LBO loans, we study the contractual terms of LBO loans. Under the CDO supply view, LBO loans are originated in anticipation that they can be funded from CDO investors. If CDOs represent a cheaper source of capital, they may affect banks' lending policies. In particular, CDO capital may allow banks to offer loans at lower spreads. Further, since banks do not fund the loans from their balance sheet, their incentive to monitor is potentially reduced. This may lead to less restrictive loan covenants if banks do not intend to monitor the firm on an on-going basis. Lower monitoring may also potentially reduce the price of credit as banks do not expect to incur monitoring costs. Since the risk of the loan is transferred to CDO investors, CDO capital may also encourage banks to lend more aggressively because they do not bear much of the risk. Therefore, we study how credit from the CDO channel affects loan pricing, covenants, and amount of bank loans that are provided for LBOs.

\section{Results}

\section{A. Evidence on Changes in Prices and Quantities}

An outward shift in the supply of credit is expected to drive up quantities and depresses prices. Hence, the CDO supply effect predicts lower loan spreads, particularly in the institutional loan tranches that CLO vehicles invest in. Figure 4 plots the volume of LBO loans against the institutional spreads for $\mathrm{BB}$ and $\mathrm{B}$ rated loans. Both spreads are at historical lows during the LBO boom period from the second half of 2004 to the first half of 2007. BB spreads were below 200 basis points during this period and rose to 600 basis points in 2008. This spike in spreads is accompanied by a sharp drop in loan volumes. The opposite movement in loan amounts and institutional spreads is consistent with a shifting supply of credit. 
To formally test this, we calculate the correlation of quarterly changes in institutional spreads and changes in both LBO loan amounts and LBO volume. For comparison, we also consider spreads on pro rata tranches. Since CDOs do not participate in the pro rata tranche, this serves as a useful control to isolate the effect of CDO investors on the pricing of credit.

Table 2 shows that changes in spreads on institutional tranches are negatively correlated with changes in loan amounts and LBO volume. The correlation ranges from -0.32 to -0.39 for loan amounts and from -0.28 to -0.30 for LBO volume, each significant at the $10 \%$ level. In sharp contrast, there is no evidence of a correlation between LBO loan amounts and volumes with pro rata spreads, indicating that the increase in credit was confined to the institutional market. This is consistent with a credit effect that occurs specifically through CDO investors, as opposed to an overall shift in the supply of credit.

\section{B. Results on Credit Supply from the Non-CLO CDO Market}

We construct two variables to measure the availability of credit in the CDO market that are not directly linked to banks' balance sheet financing capacity or to LBO loan volumes - CDO Ex-BS CLO and CDO Ex-CLO/CBO. These two variables represent $82 \%$ and $59 \%$ of the size of the total CDO market, respectively, are almost perfectly correlated with total CDO volume (correlation of 0.99). Both these CDO measures are also highly correlated with LBO volume, with a correlation of 0.95 and 0.94 , respectively. This suggests that the overall link between the LBO and CDO markets are not a mechanical result of LBO loans funded by banks being placed in CLO vehicles.

Similar evidence holds from the broader non-CDO market for structured products. The traditional structured product markets for MBS and $A B S$ are much larger than the CDO market, with total issuance volumes about two to four times as large as the CDO issuance volumes. Since both MBS and ABS markets also share similar investors to CDO markets, the correlation between issuance amounts in these markets and the CDO market is also very high, at 0.84 and 0.72 , respectively. Notably, we find that MBS and ABS issuance volumes are also very highly correlated with LBO volume, with a correlation of 0.73 and 0.57 , respectively. 
We examine the correlation between the CDO and LBO markets in a multivariate framework where we control for macroeconomic factors and other potential sources of aggregate credit supply. The control variables include GDP growth, the risk-free rate (return on the 30 day T-bill), credit spreads (Moody’s Baa corporate bond over Aaa spread), the term structure of interest rates, (10 year government bond return over 30 day T-bill), the difference between prime and fed funds rates, and the equity market risk premium (equity market less 90 day T-bill return). We also include the return on the S\&P 500 Index to capture equity valuations and an indicator for the post-Sarbanes Oxley period after June 2002.

Table 3 shows five specifications linking LBO volume to the size of the CDO market, the non-CLO CDO market, and the ABS and MBS markets. Model (1) confirms that the positive correlation between LBO volumes and CDO issuance volumes is robust to inclusion of control variables. The coefficient of 1.49 implies a partial correlation of 0.54 between the log of LBO and CDO volumes. Regressions (2) and (3) illustrate that the link between LBO and non-CLO CDO markets is also positive and significant, indicating that the close relation between the two markets is not driven by demand for LBOs. The partial correlation between the log of LBO volumes and the log of CDO Ex-BS CLO and CDO Ex-CLO/CBO and is 0.62 and 0.36, respectively. Regressions (4) and (5) show that $A B S$ and MBS issuance volumes are also positively linked to LBO volumes.

We estimate corresponding regressions for aggregate quarterly LBO loan volumes and obtain similar results. To conserve space, only two specifications are reported in models (6) and (7). In each model, measures of CDO market size have a positive effect on the volume of LBO loans originated. Among the control variables, Risk-Free Rate and GDP Growth have a positive effect on LBO volumes and loan amounts. The SOX indicator is positive but generally not significant.

The last two columns link spreads on institutional tranches of leveraged loans to the issuance volumes in the CDO market. If credit expansion through the CDO market led to higher LBO loan volumes, a negative correlation between CDO issuance and institutional spreads should be observed. Regressions (8) and (9) confirm this negative correlation. Point estimates indicate that a one standard 
deviation increase in CDO issuance volume is associated with a 38 basis points decrease in the institutional spread of the BB-rated tranches.

Overall, the aggregate level evidence indicates a clear link between the CDO and LBO markets and suggests that an expansion of credit supply through CDOs is important in explaining LBO activity. The evidence does not favor the interpretation that an increase in loan demand led to the growth of the CDO market. Yet, the possibility exists that the link between the two markets is the outcome of an unobserved factor. We now turn to bank-level and loan-level analyses to explore this possibility.

\section{Results from Bank Level Fixed-Effects Models}

We construct a bank-level panel dataset containing banks' annual LBO lending volumes and their CDO underwriting activity. We start with all the lead banks in the LBO loan sample. For each bank, we calculate the total amount of LBO loans it originates and the total volume of CDOs it underwrites in each year. For sole-led loans, we assign full lending credit to the lead bank. ${ }^{16}$ For co-led loans, we divide the loan amount equally among all the lead banks. As in Sufi (2007), the banks are consolidated with the parent holding company in the loan allocation algorithm. When banks merge, loan allocations of the acquired bank are aggregated with the acquirer's as of the effective date of the merger. Allocation of underwriting volumes across lead banks is performed similarly. Only $8.3 \%$ of the CDO issues have multiple underwriters.

Table 4 displays the ten largest LBO lead banks along with their market share in CDO underwriting. Their ranking as LBO lenders and CDO underwriters is also displayed, using their market share in the pre- and post- 2004 periods. In the post-2004 period, the top ten LBO lenders originated \$225 billion in LBO loans, with a 94\% market share in LBO lending. During this time, these top LBO lenders were all major CDO underwriters, and each ranked among the top 13 CDO underwriters, with a collective 55\% market share in CDO underwriting. Among the top 13 CDO underwriters, the three banks not among the

\footnotetext{
${ }^{16}$ As described by Sufi (2007), lead banks are primary negotiators of the loans, are responsible for collecting information and negotiating loan terms, typically hold a larger share of the loan, and charge up-front fees. Other syndicate participants maintain an arm's-length relationship with the borrower by interacting with lead banks. Our allocation of loan amounts is also consistent with how league tables for banking transactions are computed.
} 
ten largest LBO lenders were also very active in LBO lending. Merrill Lynch was the 13th in terms of LBO lending, and the other two banks were ranked 15th and 22nd, respectively. However, this tight correspondence between LBO lending and CDO underwriting activity did not exist pre-2004. Before 2004, the top ten LBO lenders had a 25\% market share in CDO underwriting market, but a 79\% share in LBO loan origination. Four of the top lenders had no CDO underwriting activity. The contrast in the overlap between LBO lending and CDO underwriting before and after 2004 suggests these two activities were much more closely linked during the LBO boom than was historically the case.

We directly test whether CDO underwriting activities affect a bank's LBO lending by estimating bank fixed-effects models of lending as in equation (1). Our LBO loan panel data contains 61 banks and 165 bank-year observations. For each bank-year, we calculate the bank’s own underwriting activity in the CDO and structured products markets using variables that correspond to our aggregate measures of market size: Total $C D O$ is the aggregate volume of CDOs underwritten by a bank in a given year; $C D O$ $E x-B S C L O$ and $C D O E x-C L O / C B O$ are measures of bank CDO underwriting activity that exclude vehicles that are set up to remove existing loans and those investing in any loans or bonds, respectively; ABS and MBS are the volumes of U.S. issued ABS and MBS underwritten by the bank in a given year. We include Lagged Total CDO, the one-year lagged Total CDO underwriting as an additional measure for banks' access to supply of credit from the CDO market. High lagged volumes of CDO underwriting will be reflective of a bank's expertise or capacity in CDO underwriting, but are not affected by its activity in LBO lending in a given year. The models include GDP Growth and Fed Funds Rate as controls for the economic environment and funding costs.

Results from the bank fixed-effects models in Table 5 show a clear link between banks' activities in CDO underwriting and their LBO lending. Model (1) shows that the volume of LBO lending in a year is positively related to its CDO underwriting volume in that year. Model (2) shows that this relation is not driven by the balance sheet CLO underwriting of banks designed to lower exposure to leveraged loans. To further disentangle causality behind the relation between LBO lending and CDO underwriting, models (3) - (6) use measures of CDO underwriting that are not affected by LBO lending activities in a given 
year. These specifications show that underwriting activity in the CDO and structured product markets is positively related to LBO lending. The two measures of non-LBO driven CDO activity, CDO ExCLO/CBO, and Lagged Total CDO are positive and significant at the 1\% level. The two broader measures for structured products underwriting activity, $A B S$ and $M B S$, are also positive and significant at the 5\% level.

The results are robust to including control variables that measure banks' financial structure and operating performance. We obtain data on the following bank characteristics from Compustat: Bank Size (measured as log of total assets), Operating Margin and Return on Equity (defined as income before tax and appropriations divided by revenue, and equity, respectively), Capital Ratio (the ratio of total equity to total assets), Liquidity (short-term investments divided by assets), and Deposits (total customer deposits over assets). Inclusion of these controls leaves the basic results unchanged. All six measures of CDO underwriting activity remain positive and significant determinants of LBO lending.

These results point to a direct link between lending policies of banks and their underwriting activities in the CDO and structured product markets. The most plausible explanation for these results is that the supply of credit from the CDO and structured product markets enabled banks to fund their leveraged lending, and the incentives to generate underwriting profits may have made them aggressive LBO lenders. The results cannot be explained by the demand for LBOs leading to greater volumes of CLO underwriting since the patterns hold for CDO vehicles that do not invest in leveraged loans such as structured product CDOs, and for the broader ABS and MBS markets. Since these results hold in a bank fixed-effects framework, they cannot be explained by the possibility of omitted variables that are correlated with both bank lending policies and CDO underwriting volumes.

\section{Loan Level Results on Allocation to Institutional Investors}

If the ability to finance loans from CDO investors led banks to be aggressive lenders, we expect that LBO loans should be heavily financed by CLO vehicles in the syndicated loan market when the bank has access to these investors through its underwriting capabilities. To test this prediction, we ideally would like to track the allocation of each loan to CLO vehicles but data do not permit this level of precision. 
However, we are able to identify a closely correlated measure, the percentage of the loan that is placed with institutional investors, by measuring the size of the institutional tranches of the loan. We expect this measure to be highly reflective of the allocation to CLO vehicles because these had become the dominant group among institutional investors during the LBO boom, accounting for $60 \%$ of primary activity in leveraged loans by 2006 (S\&P (2006)). During the sample period, the role of CLO vehicles and their share of the institutional investor universe increased steadily as the number of U.S. CLO managers rose from 27 in 2001, to 68 in 2004, and to 160 in 2007 (JP Morgan (2007)).

Panel A of Table 6 shows that during the post-2004 period, LBO were much larger and also financed much more heavily from institutional investors. We categorize loans in the following manner: revolvers and term loan A tranches are bucketed as pro rata tranches, term loans B, C and D are classified as institutional tranches, and the other tranche category includes the remaining miscellaneous tranches such as standby letters of credit and delayed draw term loans. We scale the size of these tranches by the amount of the total borrowing.

Not surprisingly, LBO loans in the post-2004 period are much larger with an average amount of \$1.8 billion compared to $\$ 224$ million in the pre-2004 period. More relevant, however, is the sharply higher proportion of the loan financed by institutional tranches. The mean size of the institutional tranche is $60 \%$ in the post-2004 period versus 44\% pre-2004. The difference in medians is even more pronounced with a 74\% institutional allocation after 2004 compared to a 44\% allocation pre-2004. These differences are statistically significant at conventional levels.

Panel B of Table 6 shows how the CDO underwriting activities of lead lending banks changed from the pre-2004 to the post-2004 period. Pre-2004, 59\% of lending banks had CDO underwriting capabilities, but 89\% were active in CDO underwriting after 2004. The average volume of CDOs underwritten by all the lead banks rose over ten-fold from $\$ 2.9$ billion to $\$ 34.5$ billion. Thus, even though LBO loan sizes rose sharply in the post-2004 period, as a percentage of CDOs underwritten by the lending banks, they actually declined significantly. 
We examine the link between CDO underwriting activities and the placement of LBO loans to CLO vehicles in a multivariate setting. The dependent variable in these tests is the fraction of the loan placed in institutional tranches. We use three variables to measure CDO underwriting for each lead arranger bank: the total volume of total CDO underwriting (Total CDO), the volume of CDOs underwritten excluding balance sheet CLOs (CDO Ex-BS CLO), and the volume of CDOs underwritten excluding CLOs and CBOs (CDO Ex-CLO/CBO). CDO Ex-BS CLO removes the effect of banks' exposure management to its LBO lending, while $C D O E x-C L O / C B O$ serves as a measure of the bank's access to the CDO investor universe that is unaffected by LBO financing activities.

Results from a Tobit model estimating the fraction of an LBO loan that is placed in institutional tranches are presented in Table 7. The models control for several deal and bank specific variables. Deal specific control variables include the size of the LBO deal measured by transaction value, the target's operating cash flow, the volatility of the target's cash flow over the past five years, the loan multiple (loan value to the target's operating cash flow), the number of lead arranging banks, and the size of the banks as measured by their total assets. To control for loan attributes we include the amount of the bank loan (relative to deal size and target's operating cash flow) and its maturity, using the weighted average maturity of all institutional tranches.

The results show a strong connection between banks' CDO underwriting and the fraction of the loan that is funded through institutional tranches. Models (1) and (2) display a positive correlation between the institutional fraction and the volume of CDO underwriting by the lead banks. The point estimates imply that a one standard deviation increase in the log of total CDO underwriting volume is associated with a $7 \%$ higher allocation to institutional tranches. The effect is slightly stronger when one uses non-LBO driven measures of CDO underwriting to alleviate concerns of reverse causality. Models (3) to (6) show that both $C D O E x-B S C L O$ and $C D O E x-C L O / C B O$ of underwriting are positively associated with the allocation to institutional investors, and the effect is of similar economic magnitude as Total CDO.

Among the control variables, larger LBOs involve a higher proportion of the loans funded through institutional tranches, suggesting that the expansion of credit through the structured credit market 
facilitated larger LBO transactions. We also find that institutional investors are more heavily involved in funding the deal when the target resides in an industry with more variable cash flows. Overall, the results suggest that access to the CDO capital through their underwriting activities allowed banks to finance a larger portion of their loan commitments from institutional investors such as CLO vehicles.

\section{E. CDO Access and Contractual Loan Terms}

We now examine how access to CDO investors and the ability to place loans into CDO vehicles affects the pricing and covenant structure in loans. If CLOs increased the supply of credit, LBO financing should be cheaper for firms due to more attractive pricing or fewer restrictive covenants, or both.

\section{Evidence on Loan Spreads}

Panel C of Table 6 displays the spreads of revolver, term loan A, and term loan B tranches. Spreads on all tranches dropped after 2004. Consistent with the growth of CLOs as important institutional investors, the drop is largest for institutional spreads which we measure by the term loan B spreads. ${ }^{17}$ The average institutional spread dropped by almost 70 basis points (or 20\%), from 340 basis points to 271 basis points after 2004. In comparison, average pro-rata spreads dropped from an average of 284 basis points to 242 basis (or 15\%). Also noticeable are the fewer term loan A tranches that occur after 2004 as they were replaced by the term loan B and other institutional term loans in recent years.

We examine the effect of CDO credit supply on borrowing costs by using the volume of CDO underwriting by a bank in a given year as a fraction of the bank's total assets. Scaling CDO underwriting volume by bank size provides a measure of the relative importance of a bank's funding from CDO investors versus other sources of funding such as deposits and wholesale loans. For each loan, we calculate this ratio, termed Lender CDO Funding, and average it across all lead banks when multiple lead arrangers are present. Panel B of Table 6 shows that this variable averages 1.1\% before 2004 but rises to $1.9 \%$ in later years. Thus, despite the rapid growth in bank assets in the post-2004 era, CDOs as a source of funding grew in importance for banks.

\footnotetext{
${ }^{17}$ We use term loan B because other institutional term loans may be junior to it or have different covenants, and the term loan B is the most common institutional term loan, accounting for 78\% of all institutional tranches after 2004. This is also consistent with the measure of institutional spreads used by LPC.
} 
Table 8 shows that Lender CDO Funding has a negative effect on institutional spreads. Models (1) to (4) find that the coefficient on Lender CDO Funding is negative and significant at the $5 \%$ level. This effect is robust to inclusion of GDP Growth, Fed Funds Rate, and Prime Rate as controls for business cycle and monetary policy effects that might affect banks' lending costs. The economic magnitude of Lender CDO Funding is sizable. A one standard deviation increase in this measure is estimated to lower institutional spreads by 17 to 20 basis points. Thus, banks' access to the CDO capital appears to reduce financing costs for borrowers. A similar pattern is also observed by Ivashina and Sun (2008) who find that demand pressure (for underlying collateral assets) from institutional investors in the syndicated loan market depressed the spreads on institutional tranches.

The lower borrowing costs resulting from structured lending are broadly consistent with the findings reported in the loan sales literature. Parlour and Plantin (2008) develop a model of loan sales based on both informational and funding reasons, and predict that in an active secondary loan market, firms borrow larger quantities and at lower prices. Guner (2006) shows that loans originated by banks that engage in more loan sales are priced with lower spreads and interprets the lower price as compensation to the borrower for having to deal with multiple banks and for the negative announcement effect resulting from the loan sale. However, the channel by which the CDO market lowers borrower funding costs is very different from the reasons studied by Guner (2006). Alternatively, it is possible that the cheaper credit is a result of pricing errors in the CDO market as documented by Coval et al. (2008a) and Brennan et al. (2008). They argue that CDO investors underestimate the risk premium they should receive because they underestimate the state price when CDOs default. The lower spreads may also reflect the lower monitoring premium banks charge for their information production services, because banks are likely to invest fewer resources in monitoring borrowers when they expect to sell the loan to CLOs.

\section{Evidence on Covenant Structure}

Credit spreads reflect only part of the funding cost equation, with the covenant structure representing the other relevant component. A hallmark of the leveraged loan markets in the 2004-07 era was the emergence of covenant-lite loans that lacked any maintenance covenants. This covenant freedom afforded 
LBO borrowers substantial flexibility in post-LBO restructuring by permitting a wide range of actions that might normally have triggered covenant violations, requiring lender approvals, enhanced monitoring, and/or higher fees. The higher risk involved for banks providing these loans was highlighted in late 2007 when market liquidity collapsed and unsold covenant-lite loans became a major source of losses for banks.

The last four columns in Table 8 report the marginal effects from probit regressions on the probability that a loan is structured as covenant-lite. In all specifications, Lender CDO Funding is associated with a higher likelihood that a loan is covenant-lite. A one standard deviation increase in Lender CDO Funding is associated with 5\%-12\% increase in the probability of the loan being covenantlite, a substantial effect considering that the unconditional probability of a covenant-lite loan is only $11 \%$. Among control variables, Bank Size has significant effect, indicating that larger banks were more likely to extend covenant-lite loans.

The prevalence of weaker covenant protection in CDO-driven loans suggests that the shift to funding from capital markets lowered the incentive for on-going monitoring by banks. The looser covenants in the structured lending model are in sharp contrast to the more restrictive covenants Drucker and Puri (2008) document for loans sold in the secondary market. This difference in covenant protection highlights a key distinction between the structured lending and the loan sales markets. In loan sales, loans are traded among banks and institutions. Since the buyer bears the risks, it has the incentive to monitor the borrower and enforce covenants. The seller (and originator) of loans thus have incentives to design tight covenants at origination to reduce information asymmetry in future sales. However, in the structured lending approach, loans are originated to be sold to a diverse set of investors in the CDO market instead of an individual buyer. These investors, well diversified by holding only a slice of a loan in a bigger collateral pool, lack the incentive and the expertise to monitor and enforce contracts. This reduces the originating banks' incentives to include restrictive covenants because they do not bear the risk of default. If the supply of credit is held constant, the lack of covenant protection ought to be priced in by CDO investors. 
Thus, our finding that covenant protection was actually weaker suggests that credit supply expanded in the CDO market.

Overall, the results highlight significant changes in the role of banks and the nature of bank lending that occurred in the wake of credit supply fueled by structured credit markets. As banks switched from the traditional originate-and-hold to the originate-to-distribute model, bank lending appears to have been driven more by their expertise in financial engineering rather than their role as information producers. Our results suggest that this disintermediation of banks was accompanied by looser covenants and cheaper credit for borrowers.

\section{Leverage Ratios in LBO Deals}

We now turn to how the access to CDO capital affected the amount of bank borrowing that was used to finance individual LBO deals. To do this, we aggregate multiple loans supporting the same deal and measure the use of bank loans for each deal. Three ratios are calculated: bank loan amount over the total funding need; bank loan amount over EBIT; and EBIT over interest payments on the bank loan. Total funding needs are calculated as the transaction value plus fees and expenses associated with the deal. Following Kaplan and Stein (1993), interest payments are estimated using the sum of the six-month LIBOR as of the effective date of the LBO deal plus the relevant credit spreads. As in Axelson et al. (2008), we distinguish contingent borrowing (revolvers) from non-contingent borrowing (all other tranches). Since revolvers are partially (or not) drawn down, including them would overestimate the use of bank loans in financing the deal. Hence, we focus on the non-contingent portion of the borrowing amount. We also calculate the measures using the contingent amount only as well as the total amount, which serves as an upper bound on borrowing amounts. These three ratios are winsorized at the $5 \%$ level to reduce noise from extreme values, primarily from the much smaller deals.

Table 9 compares the use of bank loans in deals where lending banks are active CDO underwriters (Lender CDO Funding is greater than the median) to those where banks are less active in the CDO market (Lender CDO Funding is below the median). For all three loan metrics, firms use non-contingent loans more aggressively when the lenders are active CDO underwriters. The difference is particularly large and 
significant for loan cash flow multiples, with a mean of 4.6 vs. 2.8 and median of 4.3 vs. 2.1. As a fraction of total funding needs, deals funded by active CDO banks borrow 41.8\% (median of 38.8\%), compared to $35.5 \%$ (median of 29\%) for other deals. Interestingly, deals financed by active CDO banks use fewer revolvers, perhaps because these loans typically stay on the bank's balance sheet and are not funded through the CDO channel. Overall, deals financed by active CDO banks rely more heavily on bank loans.

To address concerns on reverse causality, we also perform the comparison of bank loans splitting the sample according to the lender's CDO funding excluding balance sheet CLOs (untabulated to conserve space) and lender's CDO funding excluding all CLOs and CBOs. Panel B of Table 9 shows that very similar inferences are obtained with this approach. Banks that are active CDO underwriters in markets other than CLOs and CBOs also extend more loans relative to funding needs and the target's cash flows.

Table 10 tests the effect of lead banks' CDO funding on the use of bank loans, controlling for characteristics of the LBO targets. The positive effect of Lender CDO Funding on the use of noncontingent loans persists and is significant at least at the $10 \%$ level. The results are stronger for the loan to cash flow multiple. A one standard deviation increase in Lender CDO Funding leads to additional noncontingent borrowing equal to 70\% of the target's cash flow. We also examine the bank's CDO funding excluding its activities in the balance sheet CLO market as well as excluding all funding from the CLO and CBO markets. Both of these measures of banks' CDO funding are also positively related to the use of loans. Thus, the effect on bank borrowing remains significant in the multivariate framework, indicating that active CDO banks helped support more aggressive use of bank loans in LBO transactions.

Overall, the deal-level analysis suggests that the more connected a bank is to the CDO investor base through its underwriting efforts, the more aggressively the bank lends for LBOs. The better access to credit for borrowers is consistent with the findings in the loan sales literature. Drucker and Puri (2008) show that loan sales, an alternative channel for banks to reduce their loan exposures, increase credit access for borrowers. 


\section{Implications For Nature of LBO Transactions}

The evidence suggests that the structured credit from CDO investors encouraged banks not only to lend more to finance LBO deals, but also to offer cheaper prices and looser covenants. Did this easy credit lead to bad LBO deals, those that were riskier or overpriced? In the first LBO boom during the late 1980s, Kaplan and Stein (1993) document an "overheated” market in which deals were overpriced, riskier, and financed more from junk bond investors than from banks, and which performed worse post-buyout. To explore whether the structured credit market led to a similar pattern of "overheating” in the recent LBO boom, we examine target firm characteristics, financing structure, and the pricing of LBO deals.

\section{A. Target Characteristics}

Panel A of Table 11 compares characteristics of CDO-driven deals (i.e. where the bank is heavily reliant on CDO funding, based on the median of Lender CDO Funding) to the non-CDO-driven deals. The CDO-driven deals are much larger. The average (median) transaction value for these deals is $\$ 3.04$ billion (\$923 million), compared to \$763 million (\$129 million) for non-CDO-driven deals. CDO-driven deals involve much better performing targets, with average operating cash flow margin of 15\% (median of $14 \%$ ), compared to $9 \%$ (median of $11 \%$ ) for non-CDO-driven deals. CDO-driven deals are also less likely to be unprofitable companies and have better growth opportunities, as measured by the market-tobook ratio. Prior to the LBO, they have similar leverage to non-CDO-driven deals.

Conventional measures for potential value enhancement in LBOs such as free cash flow and tax payments are higher in CDO-driven deals. These targets generate, on average, 78\% (median of 32\%) more free cash flow than non-CDO-driven deals, and they pay twice as much taxes. The higher free cash flows in CDO-driven deals suggest that agency problems between management and shareholders might be more severe in these firms (Jensen (1986), Kaplan (1989b)). Therefore, by forcing management to use free cash flow more effectively, LBOs of the CDO-driven deals have the potential for creating more value. Moreover, the higher tax payment by targets of CDO-driven deals suggests that these firms might increase their interest tax shields by levering up (Kaplan 1989a). The higher level of free cash flows and tax payments in these deals suggest that the potential for efficiency improvements is higher. 
CDO-driven deals involve targets that are less risky. All measures of operating risk that we examine, including the volatility of cash flows, volatility of growth in cash flows, and volatility of growth in operating margin are at least 50\% higher for non-CDO driven deals than they are for CDO-driven deals. The lower operating risk characteristics of CDO-driven deals suggest that they are better candidates for highly levered transactions.

Thus, inspection of the firm characteristics does not suggest that structured credit promoted riskier LBO transactions. Instead, it appears that it allowed much larger firms to be taken private. It is possible that these firms were suitable or desirable candidates for LBOs prior to the LBO boom but that the growth in structured credit created a mechanism for financing these transactions that overcame the lending constraints of banks. ${ }^{18}$

\section{B. Financing Structure}

Even if the targets of CDO-driven deals were suitable LBO candidates, the deals could be structured with greater financial risk. Our earlier evidence shows that CDO-driven deals tend to use more bank loans, particularly non-contingent loans. Table 12 provides a more complete picture of the financing structure, where we scale the different sources of financing by the total funding need for the LBO. Not surprisingly, total funding needs are much higher for CDO-driven deals. ${ }^{19}$ Consistent with earlier results, CDO-driven deals use more term loans as well as more total bank loans.

CDO-driven deals also use more junk bonds/notes and mezzanine financing, suggesting that bank loans are not used to substitute for other forms of debt. Most importantly, the equity contribution is not reduced in these deals. Equity investors, including rollover investors, contribute, on average, 34\% of the

\footnotetext{
${ }^{18}$ A possibility is that the characteristics of LBO targets varied across different size spectrums. This might arise if the very large and safe firms that were previously constrained from going private conducted CDO-driven LBOs while the smaller and previously unconstrained LBOs involved riskier firms. However, inspection of LBO target characteristics during 2004 to 2007 across various size spectrums does not provide support for this conjecture.

${ }^{19}$ Note that total funding needs are greater than the transaction values reported in Table 11. This occurs because funding needs include the deal fees and expenses and because this analysis is based on hand collected data, which was unavailable for some smaller deals. The sample in Table 12 is slightly different from that in Table 9, which includes deals that involved some bank financing and the financing amounts were available. Table 12 includes deals with no bank loans, but excludes deals where the equity contribution cannot be identified.
} 
total funding need for both types of LBOs. Thus, it does not appear that structured credit was used to substitute for equity financing. When all financing sources are summed up, the last two rows show that the CDO-driven deals arrange more financing than needed to complete the deal. On average, CDO-driven deals arrange $15.5 \%$ additional funding, including revolvers, while non-CDO-driven deals raised 6.7\% additional funding. Excluding revolvers, CDO-driven deals, on average, arrange just enough funding to complete the deal without requiring a drawdown on their bank revolvers or using their cash holdings, while the non-CDO-driven deals have an average shortfall of $8 \%$ which would require a draw on bank revolvers or the use of existing cash holdings to complete the deal.

Overall, we do not find that the growth of structured credit led to riskier financing structures in LBO deals as equity contribution in the transactions did not decline. Instead, it appears that management teams and financial sponsors used the increased supply of credit to lock up incremental financing, possibly to provide more flexibility in funding future investment or other needs and lower the probability of financial distress.

\section{LBO Pricing}

Did structured credit lead to overpayment in LBOs? To answer this, we measure LBO pricing using Premium, the final offered price over the target's stock price a month before the announcement, and the transaction multiple FV/EBIT, the ratio of the transaction value (net of expenses and fees) to EBIT if EBIT is positive. If EBIT is negative, FV/EBIT is treated as missing. To include firms with negative EBIT, we also calculate the inverse of the transaction multiple, EBIT/FV, which is monotonic in EBIT. All three measures are winsorized at the $5 \%$ level to avoid extreme values, particularly from small deals. Panel B of Table 11 shows that CDO-driven deals, on average, involve a lower acquisition premium. The average premium in these deals is $29.7 \%$ (median of $28.3 \%$ ), compared to $36.4 \%$ (median of $31.2 \%$ ) for non-CDO-driven deals. However, this difference in premiums may reflect the overall trend towards lower acquisition premiums after 2003 documented by Bayazitova et al. (2008) since CDO-driven deals occur exclusively in the latter part of our sample period. Using EBIT/FV, we find no significant difference in transaction multiples across CDO- and non-CDO driven LBOs. 
Table 13 presents regression estimates for LBO pricing that control for other firm and industry characteristics. The results show that in all specifications, the key variable of interest, Lender CDO Funding, is not significantly related to either LBO premiums or transaction multiples. Among the control variables, larger firm size, higher market-to-book ratio, and lower leverage are associated with higher pricing multiples. Overall, these results do not suggest that funding from structured credit markets led to overpayment in LBO deals.

\section{Discussion}

Inspection of target characteristics, financing structure, and deal pricing does not suggest that structured credit created an "overheated” LBO market, a result that seems puzzling at first glance. This evidence is in contrast to Kaplan and Stein (1993)'s findings on the first LBO boom of the late 1980s. One explanation is that structured credit allowed much larger companies to be taken private than was previously possible and that these firms were desirable LBO candidates, which might have previously been insulated from the market for corporate control and stood to benefit from LBOs that reduced agency costs. It is also worth noting that the LBO boom studied by Kaplan and Stein (1993) involved much higher leverage than recent boom we study. They show that post-buyout total debt to capital was between $83 \%$ and $91 \%$ from 1986 to 1989 , indicating an equity contribution of $9 \%$ to $17 \%$, compared to an average equity contribution of $34 \%$ in our sample.

Yet, we believe our evidence should be viewed as only preliminary on the issue of efficiency. The lower leverage used in the recent boom may suggest lower value creation but may also entail lower expected costs of financial distress. The CDO-driven deals obtained more favorable financing terms and arranged more financing than needed. The less restrictive covenants provided borrowers with more flexibility. Moreover, the LBO loans were mostly institutional term loans with bullet repayment schedules. Since debt repayment is pushed towards maturity in these loans, the pressure for debt repayment is less severe. These easier terms increase the ability of LBO borrowers to survive an economic downturn and potentially lower the cost of financial distress. However, they may also increase 
the cost of economic distress by tolerating operational miscues longer. Thus, the broader issue of whether structured credit led to more or less efficient LBO transactions requires a more in-depth investigation.

\section{Conclusion}

The last few years have witnessed extraordinary developments in credit markets with a massive increase in the size of structured credit markets and an equally dramatic collapse as many credit markets shut down. We study how these large shifts in the availability of credit affected the corporate use of leverage by examining LBO transactions that rely heavily on debt financing. We argue that developments that led to the growth of structured credit contributed to increased credit supply that at least partially fueled the recent LBO boom. Our evidence highlights important linkages between structured credit, the dual role of banks in the structured credit markets as loan originators and underwriters, and the corporate use of leverage.

We are not suggesting that structured markets were the only development fueling the recent LBO boom. There is evidence that other forces were also at work. Firms during this period held on to record levels of cash and many generated sizeable cash flows, factors prone to create agency conflicts. Recent work, such as Brav et. al. (2008) have shown the emergence of activist hedge funds that sought to correct some of these agency conflicts and other papers have studied the role of financial sponsors in lowering agency costs through going private transactions. However, we believe our results do emphasize that structured credit markets can have enormous impact on the availability and pricing of credit, which in turn affect the LBO market and potentially other forms of leveraged activities.

Our results also demonstrate an important connection between the lending and underwriting activities of banks. While many papers have explored the role of commercial banks in underwriting activities, this literature has focused almost exclusively on underwriting in primary markets, such as bonds, IPOs and follow-on equity offerings. We demonstrate that underwriting activities in structured markets can also have meaningful consequences and have altered the role of banks as financial intermediators. This shift from the traditional originate-and-hold (or sell) model of lending to an 
originate-to-distribute lending model led to disintermediation of banks with greater access to credit, cheaper credit prices, and looser covenants.

Our results also suggest a potential explanation for one of the most puzzling aspects of the current financial crisis - why did large commercial banks invest heavily in CDO instruments that later proved to be a source of massive asset write-downs and losses? We suggest that the underwriting activities of commercial banks in structured credit markets might be part of the answer. Faced with attractive opportunities to profit from securities underwriting, and balance sheet constraints to fund large LBO loans, banks appear to have originated LBO loans with the intent to sell them to structured product vehicles. Regulatory initiatives towards risk-based capital management might have allowed them to pursue these activities in a manner that was friendly to their capital requirements. Further analysis of this possible explanation appears to be a useful area for future research. 


\section{References}

Acharya, Viral, and Tim Johnson, 2008, More insiders, more insider trading: Evidence from private equity buyouts, Working paper, London Business School.

Axelson, Ulf, Tim Jenkinson, Per Stromberg, and Michael S. Weisbach, 2008, Leverage and pricing in buyouts: An empirical analysis, Working paper, Swedish Institute for Financial Research.

Barclays, 2002, The Barclays capital guide to cash flow collateralized debt obligations, March 2002.

Bayazitova, Dinara, Sergey Sanzhar, and Anil Shivdasani, 2008, Why are takeover premia dropping? Working paper, University of North Carolina at Chapel Hill.

Boone, Audra L., and J. Harold Mulherin, 2008, Do private equity consortiums impede takeover competition? Working paper, University of Georgia.

Brav, Alon, Wei Jiang, Frank Partnoy, and Randall Thomas, 2008, Hedge fund activism, corporate governance, and firm performance, Journal of Finance 63, 1729-1775.

Brennan, Michael J., Julia Hein, and Ser-Huang Poon, 2008, Tranching and rating, Working paper, University of California at Los Angeles.

Citi Credit Research, 2007, Global structured credit strategy, June 26, 2007.

Coval, Joshua D., Jakub W. Jurek, and Erik Stafford, 2008a, Economic catastrophe bonds, American Economic Review, forthcoming.

Coval, Joshua D., Jakub W. Jurek, and Erik Stafford, 2008b, The economics of structured finance, Journal of Economic Perspectives, forthcoming.

Demiroglu, Cem, and Christopher James, 2007, Lender control rights and the role of private equity group reputation in buyout financing, Working paper, University of Florida.

Diamond, Douglas W., 1984, Financial intermediation and delegated monitoring, Review of Economic Studies 51, 393-414.

Diamond, Douglas W., 1991, Monitoring and reputation: The choice between bank loans and directly placed debt, Journal of Political Economy 99, 689-721.

Drucker, Steven, and Manju Puri, 2008, On loan sales, loan contracting, and lending relationships, Review of Financial Studies, forthcoming.

Faulkender, Michael and Mitchell A. Petersen, 2006, Does the source of capital affect capital structure?, Review of Financial Studies 19, 45-79.

Fitch Ratings, 2007, Inside the ratings: What credit ratings mean, August 2007.

Franke, Gunter, Markus Herrmann, and Thomas Weber, 2007, On the design of collateralized debt obligation-transactions, Working paper, University of Konstanz. 
Gande, Amar, and Anthony Saunders, 2006, Are banks still special when there is a secondary market for loans?, Working paper, Southern Methodist University.

Garrison, Kedran, 2005, Manager incentives in collateralized debt obligations, Working paper, Massachusetts Institute of Technology.

Giaccherini, Luca, and Giovanni Pepe, 2008, Basel II capital requirements for structured credit products and economic capital: A comparative analysis, working paper, Banking Supervision Department, Banca d'Italia.

Gorton, Gary, and George G. Pennacchi, 1995, Banks and loan sales: Marketing non-marketable assets, Journal of Monetary Economics 35, 389-411.

Guner, Burak A., 2006, Loan sales and the cost of corporate borrowing, Review of Financial Studies 19, 687-715.

Guo, Shourun, Edith S. Hotchkiss, andWeihong Song, 2007, Do buyouts (still) create value?, Working paper, Boston College.

Ivashina, Victoria, and Anna Kovner, 2008, The private equity advantage: Leveraged buyout firms and relationship banking, Working paper, Harvard University.

Ivashina, Victoria, and Zheng Sun, 2008, Institutional demand pressure and the cost of corporate debt, Working paper, Harvard University.

Jensen, Michael C., 1986, Agency costs of free cash flows, corporate finance and takeovers, American Economic Review 76, 323-329.

Jensen, Michael C., and William H. Meckling, 1976, Theory of the firm: Managerial behavior, agency costs, and capital structure, Journal of Financial Economics 3, 305-360.

JP Morgan, 2007, 2008 US fixed income outlook, November 23, 2007.

Kaplan, Steven N., 1989a, Management buyouts: evidence on taxes as a source of value, Journal of Finance 44, 611-632.

Kaplan, Steven N., 1989b, The effects of management buyouts on operating performance and value, Journal of Financial Economics 24, 217-254.

Kaplan, Steven N., and Jeremy C. Stein, 1993, The evolution of buyout pricing and financial structure in the 1980s, Quarterly Journal of Economics 108, 313-357.

Kaplan, Steven N., and Per Stromberg, 2009, Leveraged buyouts and private equity, Journal of Economic Perspectives 23, 121-146.

Kothari, Vinod, 2006. Securitization: The Financial Instrument of the Future (John Wiley \& Sons (Asia) Pte Ltd.). 
Leary, Mark T., 2005, Bank loan supply, lender choice, and corporate capital structure, Working paper, Cornell University.

Lemmon, Michael, and Michael Roberts, 2008, The response of corporate financing and investment to changes in the supply of credit, Journal of Financial and Quantitative Analysis, forthcoming.

Leveraged Commentary \& Data (LCD), 2007, LCD LoanStats Weekly, September 27, 2007.

Loutskina, Elena, and Philip E. Strahan, 2009, Securitization and the declining impact of bank finance on loan supply: Evidence from mortgage originations, Journal of Finance 64, 861-889.

Metrick, Andrew, and Ayoko Yasuda, 2007, The economics of private equity funds, Working paper, University of Pennsylvania.

Mian, Atif, and Amir Sufi, 2008, The consequences of mortgage credit expansion: Evidence from the U.S. mortgage default crisis, Quarterly Journal of Economics, forthcoming.

Officer, Micah S., Oguzhan Ozbas, and Berk A. Sensoy, 2008, Club deals in leveraged buyouts, Working paper, University of Southern California.

Parlour, Christine A., and Guillaume Plantin, 2008, Loan sales and relationship banking, Journal of Finance 63, 1291-1314.

Pennacchi, George G., 1988, Loan sales and the cost of bank capital, Journal of Finance 63, 375-396.

Rajan, Raghuram G., 1992, Insiders and outsiders: The choice between relationship and arm's-length debt, Journal of Finance 47, 1367-1400.

S\&P, 2006, A guide to the loan market, September 2006.

Sufi, Amir, 2007, Information asymmetry and financing arrangements: Evidence from syndicated loans, Journal of Finance 62, 629-668.

Sufi, Amir, 2009, The real effects of debt certification: Evidence from the introduction of bank loan ratings, Review of Financial Studies 22, 1659-1691. 
Table 1: Summary of the CDO and Securitization Markets

This table presents the size of the CDO and broader securitization market based on collateral assets over the 1996 and June 2008 period and for pre- and post-2004 subperiods. The data on securitized issues is from ABS Database. Data on collateral assets are unavailable for CDO issues before 2001. Hence Panel A excludes CDO issues before 2001.

\begin{tabular}{|c|c|c|c|c|c|c|}
\hline \multicolumn{7}{|c|}{ Panel A: Size of CDO Market Based on Collateral Type } \\
\hline & \multicolumn{3}{|c|}{$2001-2003$} & \multicolumn{3}{|c|}{2004 -June 2008} \\
\hline & \multicolumn{3}{|c|}{ Issuance } & \multicolumn{3}{|c|}{ Issuance } \\
\hline & $\begin{array}{l}\text { Number } \\
\text { of Issues }\end{array}$ & $\begin{array}{l}\text { Amount } \\
\text { (\$bn) }\end{array}$ & $\begin{array}{l}\% \text { of } \\
\text { Total }\end{array}$ & $\begin{array}{l}\text { Number } \\
\text { of Issues }\end{array}$ & $\begin{array}{c}\text { Amount } \\
\text { (\$bn) }\end{array}$ & $\begin{array}{l}\% \text { of } \\
\text { Total }\end{array}$ \\
\hline Structured Product CDOs & 252 & 63.9 & 29.6 & 1,243 & 556.0 & 43.8 \\
\hline \multicolumn{7}{|l|}{ Corporate Loans (CLOs) } \\
\hline Arbitrage CLOs & 153 & 46.9 & 18.0 & 891 & 431.1 & 31.4 \\
\hline Balance Sheet CLOs & 90 & 41.6 & 10.6 & 76 & 75.6 & 2.7 \\
\hline \multicolumn{7}{|l|}{ Corporate Bonds (CBOs) } \\
\hline High-Yield CBOs & 72 & 24.0 & 8.5 & 37 & 12.6 & 1.3 \\
\hline Investment-Grade CBOs & 128 & 24.8 & 15.0 & 213 & 30.3 & 7.5 \\
\hline CMBS/Real Estate & 29 & 16.0 & 3.4 & 179 & 89.4 & 6.3 \\
\hline Others & 54 & 19.8 & 6.3 & 197 & 126.5 & 6.9 \\
\hline Unknown & 74 & 17.8 & 8.7 & 19 & 1.0 & 0.7 \\
\hline Total CDO Issuance & 852 & 254.9 & 100 & 2,855 & $1,322.4$ & 100 \\
\hline \multicolumn{7}{|c|}{ Panel B: Size of Securitization Markets } \\
\hline & \multicolumn{3}{|c|}{$1996-2003$} & \multicolumn{3}{|c|}{2004 -June 2008} \\
\hline & & Issuance & & & Issuance & \\
\hline & $\begin{array}{l}\text { Number } \\
\text { of Issues }\end{array}$ & $\begin{array}{c}\text { Amount } \\
\text { (\$bn) }\end{array}$ & $\begin{array}{l}\% \text { of } \\
\text { Total }\end{array}$ & $\begin{array}{l}\text { Number } \\
\text { of Issues }\end{array}$ & $\begin{array}{c}\text { Amount } \\
\text { (\$bn) }\end{array}$ & $\begin{array}{l}\% \text { of } \\
\text { Total }\end{array}$ \\
\hline CDOs & 1,687 & 605.3 & 12.7 & 2,855 & $1,322.4$ & 16.4 \\
\hline \multicolumn{7}{|c|}{ U.S. Mortgage-Backed Securities (MBS) } \\
\hline Residential mortgages & 2,461 & 999.1 & 21.0 & 2,660 & $1,891.1$ & 23.4 \\
\hline Subprime mortgages & 812 & 349.9 & 7.4 & 929 & 713.8 & 8.8 \\
\hline Total MBS & 3,273 & $1,349.0$ & 28.4 & 3,589 & $2,604.8$ & 32.3 \\
\hline \multicolumn{7}{|c|}{ U.S. Asset-Backed Securities (ABS) } \\
\hline Home-equity loans & 1,103 & 476.7 & 10.0 & 1,261 & $1,038.0$ & 12.9 \\
\hline Auto loans/leases & 776 & 485.2 & 10.2 & 345 & 344.1 & 4.3 \\
\hline Credit cards & 724 & 452.9 & 9.5 & 504 & 331.5 & 4.1 \\
\hline Student loans & 196 & 137.9 & 2.9 & 193 & 253.8 & 3.1 \\
\hline Others & 1,814 & 534.7 & 11.2 & 1,671 & 496.5 & 6.2 \\
\hline Total ABS & 4,613 & $2,087.4$ & 43.9 & 3,974 & $2,464.0$ & 30.5 \\
\hline \multicolumn{7}{|c|}{ Non-U.S. Mortgage- and Asset-Backed Securities } \\
\hline Non-U.S. residential & 802 & 370.6 & 7.8 & 1021 & $1,229.9$ & 15.2 \\
\hline Auto loans/leases & 150 & 42.9 & 0.9 & 104 & 76.6 & 0.9 \\
\hline Credit cards & 155 & 62.6 & 1.3 & 86 & 41.7 & 0.5 \\
\hline Others & 638 & 238.7 & 5.0 & 409 & 330.6 & 4.1 \\
\hline Total Non-U.S. MBS/ABS & 1,745 & 714.9 & 15.0 & 1,620 & $1,678.7$ & 20.8 \\
\hline Total Securitization Issuance & 11,318 & $4,756.7$ & 100 & 12,038 & $8,070.0$ & 100 \\
\hline
\end{tabular}


Table 2: Correlation of Quarterly Changes in Spreads of Leveraged Loans, LBO Volume, and Loan Amounts This table reports Pearson correlation of quarterly changes in spreads of leveraged loans, LBO volume and LBO loan volume from 1998 to June 2008. Spreads of leveraged loans, provided by Loan Pricing Corporation (LPC), are quarterly spreads over LIBOR of institutional and pro rata tranches for bank loans rated at BB and B, respectively. Data on average spreads is available since 1998. P-value testing the null that the correlation is equal to zero is reported along with the number of observations.

\begin{tabular}{|c|c|c|c|c|c|}
\hline & & \multicolumn{2}{|c|}{$\begin{array}{c}\text { Changes in Spread on Institutional } \\
\text { Tranches }\end{array}$} & \multicolumn{2}{|c|}{$\begin{array}{c}\text { Changes in Spread on Pro Rata } \\
\text { Tranches }\end{array}$} \\
\hline & & BB Rated & B Rated & BB Rated & B Rated \\
\hline \multirow{3}{*}{$\begin{array}{l}\text { Changes in } \\
\text { LBO Loan } \\
\text { Amount }\end{array}$} & Correlation & -0.32 & -0.39 & -0.11 & 0.04 \\
\hline & p-value & 0.04 & 0.01 & 0.49 & 0.80 \\
\hline & Number of obs. & 41 & 41 & 39 & 37 \\
\hline \multirow{3}{*}{$\begin{array}{l}\text { Changes in } \\
\text { LBO } \\
\text { Volume }\end{array}$} & Correlation & -0.28 & -0.30 & -0.11 & 0.15 \\
\hline & p-value & 0.08 & 0.05 & 0.52 & 0.37 \\
\hline & Number of obs. & 41 & 41 & 39 & 37 \\
\hline
\end{tabular}


Table 3: Regressions of LBO Market Size on the Size of CDO and Securitization Market

Regressions of quarterly LBO volume, loan amounts and spreads of leveraged loans for the 345 LBO deals. LBO loan amount is the aggregate of long-term bank loan borrowing amount for all the sample deals. $\log ($ Total CDO) includes all types of CDOs; $\log (C D O E x-B S C L O)$ excludes balance-sheet CLOs; $\log (C D O E x-C L O / C B O)$ excludes CDOs backed on corporate loans (CLO) or bonds (CBO); $\log (A B S)$ and $\log (M B S)$ include issuance amounts of ABS and MBS in the U.S. SOX Indicator is a dummy that equals one after June 2002 and 0 otherwise. GDP Growth is seasonally adjusted percentage change of GDP over a year earlier. S\&P 500 Return is measured over the year prior to the relevant quarter. Credit Spread is the spread of 10-year Moody's Baa bonds over Aaa bonds. Risk Premium is calculated as value-weighted market return minus return on 90-day bills. Risk-Free Rate is the return on 30-day T-bills. Term Structure is measured as 10-year government bond return minus return on 30-day T-bills. The first row reports the estimated coefficient and the second row the corresponding t-statistic. ***, **, * indicates statistical significance at the $1 \%, 5 \%$, and $10 \%$ levels, respectively.

\begin{tabular}{|c|c|c|c|c|c|c|c|c|c|}
\hline & \multicolumn{5}{|c|}{ Log (LBO Volume) } & \multicolumn{2}{|c|}{$\begin{array}{l}\text { Log (LBO Loan } \\
\text { Amount) }\end{array}$} & \multicolumn{2}{|c|}{$\begin{array}{c}\text { Spread of } \\
\text { Leveraged Loan }\end{array}$} \\
\hline & $(1)$ & (2) & (3) & (4) & (5) & (6) & $(7)$ & $\begin{array}{c}\text { BB Rated } \\
(8)\end{array}$ & $\begin{array}{l}\text { B Rated } \\
(9)\end{array}$ \\
\hline $\log ($ Total CDO) & $\begin{array}{l}1.49 \\
3.59 * * *\end{array}$ & & & & & & & $\begin{array}{l}-108.14 \\
5.81^{* * *}\end{array}$ & $\begin{array}{l}-98.09 \\
6.37 * * *\end{array}$ \\
\hline $\begin{array}{l}\log (C D O E x-B S \\
\quad C L O)\end{array}$ & & $\begin{array}{l}1.55 \\
3.58^{* * *}\end{array}$ & & & & & & & \\
\hline $\begin{array}{l}\log (C D O E X- \\
\quad C L O / C B O)\end{array}$ & & & $\begin{array}{l}1.08 \\
2.56^{* *}\end{array}$ & & & $\begin{array}{l}1.02 \\
2.24^{* *}\end{array}$ & & & \\
\hline $\log (A B S)$ & & & & $\begin{array}{l}2.39 \\
2.87 * * *\end{array}$ & & & $\begin{array}{l}2.23 \\
2.47^{* *}\end{array}$ & & \\
\hline $\log (M B S)$ & & & & & $\begin{array}{l}1.04 \\
2.76^{* * *}\end{array}$ & & & & \\
\hline $\begin{array}{c}\text { Prime Over Fed } \\
\text { Funds Rate }\end{array}$ & $\begin{array}{l}2.06 \\
0.25\end{array}$ & $\begin{array}{l}-0.74 \\
0.09\end{array}$ & $\begin{array}{l}1.28 \\
0.14\end{array}$ & $\begin{array}{l}8.62 \\
0.96\end{array}$ & $\begin{array}{l}0.90 \\
0.10\end{array}$ & $\begin{array}{l}2.22 \\
0.23\end{array}$ & $\begin{array}{l}9.10 \\
0.94\end{array}$ & $\begin{array}{l}544.30 \\
1.96^{*}\end{array}$ & $\begin{array}{l}420.10 \\
1.83^{*}\end{array}$ \\
\hline Credit Spread & $\begin{array}{l}0.91 \\
0.49\end{array}$ & $\begin{array}{l}0.78 \\
0.42\end{array}$ & $\begin{array}{l}0.88 \\
0.45\end{array}$ & $\begin{array}{l}1.56 \\
0.81\end{array}$ & $\begin{array}{l}1.80 \\
0.92\end{array}$ & $\begin{array}{l}1.79 \\
0.84\end{array}$ & $\begin{array}{l}2.42 \\
1.16\end{array}$ & $\begin{array}{l}201.67 \\
3.60^{* * *}\end{array}$ & $\begin{array}{l}231.09 \\
4.99^{* * *}\end{array}$ \\
\hline SOX Indicator & $\begin{array}{l}1.01 \\
1.13\end{array}$ & $\begin{array}{l}0.46 \\
0.45\end{array}$ & $\begin{array}{l}1.68 \\
1.82 *\end{array}$ & $\begin{array}{l}1.41 \\
1.52\end{array}$ & $\begin{array}{l}1.53 \\
1.65^{*}\end{array}$ & $\begin{array}{l}1.59 \\
1.60\end{array}$ & $\begin{array}{l}1.35 \\
1.34\end{array}$ & $\begin{array}{l}97.50 \\
3.11^{* * *}\end{array}$ & $\begin{array}{l}72.11 \\
2.78^{* * *}\end{array}$ \\
\hline GDP Growth & $\begin{array}{l}0.50 \\
1.74^{*}\end{array}$ & $\begin{array}{l}0.53 \\
1.82 *\end{array}$ & $\begin{array}{l}0.31 \\
1.02\end{array}$ & $\begin{array}{l}0.41 \\
1.36\end{array}$ & $\begin{array}{l}0.54 \\
1.75 *\end{array}$ & $\begin{array}{l}0.69 \\
2.06^{* *}\end{array}$ & $\begin{array}{l}0.78 \\
2.37^{* *}\end{array}$ & $\begin{array}{l}-6.16 \\
0.70\end{array}$ & $\begin{array}{l}-8.60 \\
1.19\end{array}$ \\
\hline S\&P 500 Return & $\begin{array}{l}-0.05 \\
0.86\end{array}$ & $\begin{array}{l}-0.05 \\
0.97\end{array}$ & $\begin{array}{l}-0.06 \\
1.15\end{array}$ & $\begin{array}{l}-0.06 \\
1.03\end{array}$ & $\begin{array}{l}-0.05 \\
0.93\end{array}$ & $\begin{array}{l}-0.04 \\
0.70\end{array}$ & $\begin{array}{l}-0.04 \\
0.58\end{array}$ & $\begin{array}{l}0.35 \\
0.20\end{array}$ & $\begin{array}{l}-1.44 \\
1.01\end{array}$ \\
\hline Risk Premium & $\begin{array}{l}0.04 \\
0.82\end{array}$ & $\begin{array}{l}0.05 \\
0.98\end{array}$ & $\begin{array}{l}0.06 \\
1.10\end{array}$ & $\begin{array}{l}0.06 \\
1.13\end{array}$ & $\begin{array}{l}0.05 \\
0.96\end{array}$ & $\begin{array}{l}0.03 \\
0.54\end{array}$ & $\begin{array}{l}0.03 \\
0.55\end{array}$ & $\begin{array}{l}-0.23 \\
0.14\end{array}$ & $\begin{array}{l}1.41 \\
1.06\end{array}$ \\
\hline Risk-Free Rate & $\begin{array}{l}0.62 \\
2.45^{* *}\end{array}$ & $\begin{array}{l}0.62 \\
2.44^{* *}\end{array}$ & $\begin{array}{l}0.72 \\
2.69 * *\end{array}$ & $\begin{array}{l}1.02 \\
4.41^{* * *}\end{array}$ & $\begin{array}{l}1.08 \\
4.60^{* * *}\end{array}$ & $\begin{array}{l}0.76 \\
2.62 * *\end{array}$ & $\begin{array}{l}1.04 \\
4.15^{* * *}\end{array}$ & $\begin{array}{l}27.55 \\
3.17^{* * *}\end{array}$ & $\begin{array}{l}26.03 \\
3.62^{* * *}\end{array}$ \\
\hline Term Structure & $\begin{array}{l}0.02 \\
0.83\end{array}$ & $\begin{array}{l}0.03 \\
1.29\end{array}$ & $\begin{array}{l}0.02 \\
1.04\end{array}$ & $\begin{array}{l}0.03 \\
1.22\end{array}$ & $\begin{array}{l}0.03 \\
1.18\end{array}$ & $\begin{array}{l}0.03 \\
1.20\end{array}$ & $\begin{array}{l}0.03 \\
1.34\end{array}$ & $\begin{array}{l}-0.27 \\
0.38\end{array}$ & $\begin{array}{l}-0.11 \\
0.18\end{array}$ \\
\hline Constant & $\begin{array}{l}-19.90 \\
0.78\end{array}$ & $\begin{array}{l}-11.55 \\
0.45\end{array}$ & $\begin{array}{l}-12.38 \\
0.45\end{array}$ & $\begin{array}{l}-53.29 \\
1.75^{*}\end{array}$ & $\begin{array}{l}-15.55 \\
0.58\end{array}$ & $\begin{array}{l}-18.34 \\
0.62\end{array}$ & $\begin{array}{l}-56.55 \\
1.71^{*}\end{array}$ & $\begin{array}{l}-548.62 \\
0.63\end{array}$ & $\begin{array}{l}-206.73 \\
0.29\end{array}$ \\
\hline Observations & 49 & 49 & 49 & 49 & 49 & 49 & 49 & 41 & 41 \\
\hline R-squared & 0.61 & 0.61 & 0.56 & 0.57 & 0.57 & 0.55 & 0.56 & 0.72 & 0.81 \\
\hline
\end{tabular}


Table 4: Top Lead Banks of LBO Loans and Their Market Share in CDO Underwriting

This table reports the top ten lead banks in 247 LBO loans where lead banks can be identified and their market share in CDO underwriting over the two subperiods: 1996 to 2003, and 2004 to June 2008. Only long-term loans and tranches are included in the LBO loan sample. The amount of each loan is distributed equally among all the lead banks when more than one bank serves as the lead arranger. LBO lending for a bank is the total amount of the share of the loans the bank arranged. In the case of bank mergers, all the credit to the target bank is aggregated into the acquiring bank at the effective date, and the emerging bank inherits the acquirer. Market share of LBO lending is calculated as the share of loans within our LBO loan sample. CDO underwriting amount is the total amount of CDOs a bank underwrites. In deals with multiple underwriters, CDO issuance amount is equally credited to all underwriters. Ranking of CDO underwriting of banks are calculated based on underwriting market share in the CDO market. When a bank never underwrites any CDOs, the rank is denoted as "n.a.".

\begin{tabular}{|c|c|c|c|c|c|c|c|}
\hline \multicolumn{8}{|c|}{ 1996-2003 } \\
\hline & \multicolumn{4}{|c|}{ LBO Lending } & \multicolumn{3}{|c|}{ CDO Underwriting } \\
\hline Bank & Rank & $\begin{array}{l}\text { No. of } \\
\text { Loans }\end{array}$ & $\begin{array}{c}\text { Amount of } \\
\text { Loans (\$bn) }\end{array}$ & $\begin{array}{c}\text { Market } \\
\text { Share (\%) }\end{array}$ & $\begin{array}{c}\text { Amount } \\
(\$ b n)\end{array}$ & $\begin{array}{c}\text { Market } \\
\text { Share (\%) }\end{array}$ & Rank \\
\hline JP Morgan & 1 & 25 & 10.6 & 36.5 & 27.3 & 4.5 & 8 \\
\hline Bank of America & 2 & 19 & 2.9 & 9.8 & 7.8 & 1.3 & 19 \\
\hline Deutsche Bank & 3 & 10 & 2.3 & 7.9 & 46.6 & 7.7 & 4 \\
\hline Credit Suisse & 4 & 9 & 2.0 & 6.7 & 51.9 & 8.6 & 2 \\
\hline Bank of Nova Scotia & 5 & 2 & 1.3 & 4.4 & 0 & 0 & n.a. \\
\hline Wachovia Bank & 6 & 6 & 1.0 & 3.4 & 14.5 & 2.4 & 12 \\
\hline FleetBoston & 7 & 8 & 1.0 & 3.4 & 0 & 0 & n.a. \\
\hline Bankers Trust & 8 & 5 & 0.7 & 2.4 & 5.7 & 0.9 & 23 \\
\hline BankBoston & 9 & 4 & 0.6 & 2.1 & 0 & 0 & n.a. \\
\hline Wells Fargo & 10 & 5 & 0.6 & 2.1 & 0 & 0 & n.a. \\
\hline Total & & & $\$ 22.9$ & 78.9 & $\$ 153.9$ & 25.5 & \\
\hline \multicolumn{8}{|c|}{ 2004-June 2008} \\
\hline & \multicolumn{4}{|c|}{ LBO Lending } & \multicolumn{3}{|c|}{ CDO Underwriting } \\
\hline Bank & Rank & $\begin{array}{l}\text { No. of } \\
\text { Loans }\end{array}$ & $\begin{array}{c}\text { Amount of } \\
\text { Loans (\$bn) }\end{array}$ & $\begin{array}{c}\text { Market } \\
\text { Share (\%) }\end{array}$ & $\begin{array}{c}\text { Amount } \\
(\$ b n)\end{array}$ & $\begin{array}{c}\text { Market } \\
\text { Share (\%) }\end{array}$ & Rank \\
\hline Citigroup & 1 & 24 & 44.9 & 18.7 & 121.5 & 9.2 & 2 \\
\hline JP Morgan & 2 & 34 & 34.0 & 14.1 & 60.6 & 4.6 & 9 \\
\hline Bank of America & 3 & 22 & 30.9 & 12.8 & 54.2 & 4.1 & 12 \\
\hline Credit Suisse & 4 & 32 & 30.4 & 12.6 & 58.6 & 4.4 & 10 \\
\hline Deutsche Bank & 5 & 20 & 23.2 & 9.6 & 98.8 & 7.5 & 3 \\
\hline Goldman Sachs & 6 & 22 & 22.9 & 9.5 & 80.8 & 6.1 & 4 \\
\hline Lehman Brothers & 7 & 10 & 18.7 & 7.8 & 65.6 & 5.0 & 6 \\
\hline Morgan Stanley & 8 & 13 & 10.3 & 4.3 & 45.5 & 3.5 & 13 \\
\hline Barclays Bank & 9 & 4 & 5.1 & 2.1 & 64.9 & 4.9 & 7 \\
\hline Wachovia Bank & 10 & 11 & 4.9 & 2.0 & 77.1 & 5.8 & 5 \\
\hline Total & & & $\$ 225.4$ & 93.6 & $\$ 727.5$ & 55.2 & \\
\hline
\end{tabular}




\section{Table 5: Bank Fixed-Effects Panel Regression of Annual LBO Lending on CDO Underwriting Activity}

This table presents fixed-effects regression of the following model in a bank-year panel:

$$
\text { LBOLending }_{i t}=\sum_{i=1}^{K} \alpha_{i}+\beta * C D O_{i t}+\gamma^{\prime} * X_{i t}+\delta^{\prime} * Z_{t}+\varepsilon_{i t} .
$$

The dependent variable $L B O$ Lending $_{i t}$ is logarithm of the total amount of LBO loans bank $i$ arrange in year $t . \alpha_{i}$ is the fixed-effect for bank $i . C D O_{i t}$ denotes underwriting activity in the CDO and other securitized market for bank $i$ in year $t$. Specifically, $\log (\operatorname{Total} C D O)$ is logarithm of the amount of total CDOs bank $i$ underwrites in year $t ; \log (C D O E x$-BS CLO) excludes CDOs backed by corporate loans and for balance-sheet purpose; $\log (C D O E x$-CLO/CBO) excludes CDOs backed by corporate loans or bonds; $\log (\operatorname{Lagged}$ Total CDO) includes all CDOs underwritten in year $t-1 ; \log (A B S)$ and $\log (M B S)$ are logarithm of the amount of ABS and MBS the bank underwrites in U.S. in year $t$, respectively. One is added to all these measures before taking log to avoid zero values. $X_{i t}$ refers to time-varying bank characteristics. Financial data for banks are from Compustat Global Financial Service. Bank Size is logarithm of total assets of the bank. Operating Margin and Return on Equity are calculated as income before tax and appropriations divided by total revenue and total equity, respectively. Capital Ratio is total equity divided by total assets. Liquidity is defined as short-term investment divided by total assets. Deposit is total customer deposit divided by total assets, and Deposit Squared is the square of Deposit. $Z_{t}$ refers to time-varying macro variables, including annual GDP Growth and Fed Funds Rate. For each independent variable, the first row reports the estimated coefficient and the second row the corresponding t-statistic. ***, **, * indicates statistical significance at the $1 \%, 5 \%$, and $10 \%$ levels, respectively. 


\begin{tabular}{|c|c|c|c|c|c|c|c|c|c|c|c|c|}
\hline & $(1)$ & $(2)$ & (3) & (4) & $(5)$ & $(6)$ & $(7)$ & $(8)$ & $(9)$ & $(10)$ & $(11)$ & $(12)$ \\
\hline $\log ($ Total CDO) & $\begin{array}{l}0.31 \\
4.24 * * *\end{array}$ & & & & & & $\begin{array}{l}0.17 \\
2.18^{* *}\end{array}$ & & & & & \\
\hline $\log (C D O E x-B S C L O)$ & & $\begin{array}{l}0.33 \\
4.89 * * *\end{array}$ & & & & & & $\begin{array}{l}0.22 \\
3.02 * * *\end{array}$ & & & & \\
\hline $\log (C D O E x-C L O / C B O)$ & & & $\begin{array}{l}0.35 \\
4.67 * * *\end{array}$ & & & & & & $\begin{array}{l}0.24 \\
2.98^{* * *}\end{array}$ & & & \\
\hline Log(Lagged Total CDO) & & & & $\begin{array}{l}0.24 \\
4.24^{* * *}\end{array}$ & & & & & & $\begin{array}{l}0.19 \\
3.42^{* * *}\end{array}$ & & \\
\hline $\log (A B S)$ & & & & & $\begin{array}{l}0.17 \\
2.35 * *\end{array}$ & & & & & & $\begin{array}{l}0.12 \\
1.69 *\end{array}$ & \\
\hline $\log (M B S)$ & & & & & & $\begin{array}{l}0.17 \\
2.95^{* * *}\end{array}$ & & & & & & $\begin{array}{l}0.11 \\
2.06^{* *}\end{array}$ \\
\hline Bank Size & & & & & & & $\begin{array}{l}0.33 \\
2.42^{* *}\end{array}$ & $\begin{array}{l}0.30 \\
2.23^{* *}\end{array}$ & $\begin{array}{l}0.31 \\
2.34^{* *}\end{array}$ & $\begin{array}{l}0.36 \\
2.79 * * *\end{array}$ & $\begin{array}{l}0.37 \\
2.78 * * *\end{array}$ & $\begin{array}{l}0.35 \\
2.61^{* *}\end{array}$ \\
\hline Operating Margin & & & & & & & $\begin{array}{l}5.28 \\
0.93\end{array}$ & $\begin{array}{l}4.56 \\
0.83\end{array}$ & $\begin{array}{l}4.12 \\
0.75\end{array}$ & $\begin{array}{l}6.82 \\
1.30\end{array}$ & $\begin{array}{l}7.73 \\
1.40\end{array}$ & $\begin{array}{l}7.98 \\
1.47\end{array}$ \\
\hline Return on Equity & & & & & & & $\begin{array}{l}-1.52 \\
0.46\end{array}$ & $\begin{array}{l}-1.22 \\
0.38\end{array}$ & $\begin{array}{l}-1.10 \\
0.34\end{array}$ & $\begin{array}{l}-1.90 \\
0.61\end{array}$ & $\begin{array}{l}-3.40 \\
1.06\end{array}$ & $\begin{array}{l}-3.01 \\
0.94\end{array}$ \\
\hline Capital Ratio & & & & & & & $\begin{array}{l}22.14 \\
1.26\end{array}$ & $\begin{array}{l}24.35 \\
1.41\end{array}$ & $\begin{array}{l}26.26 \\
1.52\end{array}$ & $\begin{array}{l}18.20 \\
1.07\end{array}$ & $\begin{array}{l}22.33 \\
1.25\end{array}$ & $\begin{array}{l}20.22 \\
1.14\end{array}$ \\
\hline Liquidity & & & & & & & $\begin{array}{l}-5.71 \\
1.75^{*}\end{array}$ & $\begin{array}{l}-5.78 \\
1.81 *\end{array}$ & $\begin{array}{l}-6.28 \\
1.97^{*}\end{array}$ & $\begin{array}{l}-4.93 \\
1.56\end{array}$ & $\begin{array}{l}-6.37 \\
1.93 *\end{array}$ & $\begin{array}{l}-6.30 \\
1.92 *\end{array}$ \\
\hline Deposit & & & & & & & $\begin{array}{l}18.41 \\
1.89 *\end{array}$ & $\begin{array}{l}17.96 \\
1.89 *\end{array}$ & $\begin{array}{l}17.91 \\
1.88^{*}\end{array}$ & $\begin{array}{l}20.11 \\
2.15^{* *}\end{array}$ & $\begin{array}{l}19.68 \\
2.00^{* *}\end{array}$ & $\begin{array}{l}18.89 \\
1.94 *\end{array}$ \\
\hline Deposit Squared & & & & & & & $\begin{array}{l}-21.00 \\
2.00 * *\end{array}$ & $\begin{array}{l}-20.30 \\
1.99 * *\end{array}$ & $\begin{array}{l}-20.39 \\
1.99 * *\end{array}$ & $\begin{array}{l}-22.76 \\
2.27^{* *}\end{array}$ & $\begin{array}{l}-23.43 \\
2.22 * *\end{array}$ & $\begin{array}{l}-22.45 \\
2.15^{* *}\end{array}$ \\
\hline Fed Funds Rate & $\begin{array}{l}0.21 \\
2.27^{* *}\end{array}$ & $\begin{array}{l}0.24 \\
2.63^{* * *}\end{array}$ & $\begin{array}{l}0.22 \\
2.42 * *\end{array}$ & $\begin{array}{l}0.24 \\
2.55^{* *}\end{array}$ & $\begin{array}{l}0.20 \\
1.96^{*}\end{array}$ & $\begin{array}{l}0.21 \\
2.11^{* *}\end{array}$ & $\begin{array}{l}0.23 \\
2.06^{* *}\end{array}$ & $\begin{array}{l}0.25 \\
2.28 * *\end{array}$ & $\begin{array}{l}0.23 \\
2.12^{* *}\end{array}$ & $\begin{array}{l}0.30 \\
2.72 * * *\end{array}$ & $\begin{array}{l}0.28 \\
2.41^{* *}\end{array}$ & $\begin{array}{l}0.27 \\
2.41^{* *}\end{array}$ \\
\hline GDP Growth & $\begin{array}{l}0.19 \\
1.33\end{array}$ & $\begin{array}{l}0.24 \\
1.67^{*}\end{array}$ & $\begin{array}{l}0.22 \\
1.50\end{array}$ & $\begin{array}{l}0.22 \\
1.46\end{array}$ & $\begin{array}{l}0.11 \\
0.73\end{array}$ & $\begin{array}{l}0.15 \\
0.97\end{array}$ & $\begin{array}{l}0.06 \\
0.36\end{array}$ & $\begin{array}{l}0.10 \\
0.68\end{array}$ & $\begin{array}{l}0.09 \\
0.61\end{array}$ & $\begin{array}{l}0.10 \\
0.66\end{array}$ & $\begin{array}{l}0.02 \\
0.13\end{array}$ & $\begin{array}{l}0.03 \\
0.20\end{array}$ \\
\hline Constant & $\begin{array}{l}2.11 \\
1.76^{*}\end{array}$ & $\begin{array}{l}1.67 \\
1.41\end{array}$ & $\begin{array}{l}1.86 \\
1.56\end{array}$ & $\begin{array}{l}2.36 \\
2.01^{* *}\end{array}$ & $\begin{array}{l}3.25 \\
2.56 * *\end{array}$ & $\begin{array}{l}3.18 \\
2.65 * * *\end{array}$ & $\begin{array}{l}-4.74 \\
1.56\end{array}$ & $\begin{array}{l}-4.95 \\
1.67^{*}\end{array}$ & $\begin{array}{l}-5.01 \\
1.68 *\end{array}$ & $\begin{array}{l}-5.91 \\
1.99 * *\end{array}$ & $\begin{array}{l}-4.99 \\
1.60\end{array}$ & $\begin{array}{l}-4.47 \\
1.47\end{array}$ \\
\hline $\begin{array}{l}\text { Observations } \\
\text { Number of banks } \\
\text { R-squared }\end{array}$ & $\begin{array}{l}161 \\
59 \\
0.17 \\
\end{array}$ & $\begin{array}{l}161 \\
59 \\
0.21 \\
\end{array}$ & $\begin{array}{l}161 \\
59 \\
0.20\end{array}$ & $\begin{array}{l}161 \\
59 \\
0.17\end{array}$ & $\begin{array}{l}161 \\
59 \\
0.07\end{array}$ & $\begin{array}{l}161 \\
59 \\
0.10 \\
\end{array}$ & $\begin{array}{l}133 \\
40 \\
0.35\end{array}$ & $\begin{array}{l}133 \\
40 \\
0.38 \\
\end{array}$ & $\begin{array}{l}133 \\
40 \\
0.38 \\
\end{array}$ & $\begin{array}{l}133 \\
40 \\
0.40\end{array}$ & $\begin{array}{l}133 \\
40 \\
0.33\end{array}$ & $\begin{array}{l}133 \\
40 \\
0.34\end{array}$ \\
\hline
\end{tabular}


Table 6: LBO Loan Tranche Structure, Lead Bank Characteristics, and Loan Pricing

This table reports summary statistics for 265 loans backing LBO deals with borrowing amounts available. Loan contract terms are from DealScan and supplemented with manually collected information from proxy filings. Only long-term tranches are included. Panel A presents the tranche structure. Panel B reports CDO underwriting activity of the lead banks. Total CDO underwriting is the aggregate CDO underwriting amount of all lead banks. Lender CDO funding is defined as a bank's CDO underwriting amount divided by the bank's total assets, averaged across all lead banks in the loan. Panel C shows spreads and covenants of the loans. Covenant-lite loans are identified from S\&P's LCD. Difference in mean and median between the two subperiods is denoted by ***, **, * to indicate statistical significance at the $1 \%, 5 \%$, and $10 \%$ levels, respectively.

\begin{tabular}{|c|c|c|c|c|c|c|}
\hline \multicolumn{7}{|c|}{ Panel A: Loan Tranche Structure } \\
\hline & \multicolumn{3}{|c|}{$1996-2003$} & \multicolumn{3}{|c|}{ 2004-June 2008} \\
\hline & $\mathrm{N}$ & Mean & Median & $\mathrm{N}$ & Mean & Median \\
\hline Loan amount (\$ml) & 131 & 223.9 & 125 & 134 & $1822.7 * * *$ & $587.5^{* * *}$ \\
\hline \multicolumn{7}{|l|}{ Pro rata tranches } \\
\hline Fraction of revolver & 131 & $30.2 \%$ & $23.4 \%$ & 134 & $26.6 \%$ & $15.4 \% * *$ \\
\hline Fraction of term loan A & 131 & $14.1 \%$ & $0 \%$ & 134 & $4.8 \% * * *$ & $0 \%$ \\
\hline Total pro rata tranches & 131 & $44.3 \%$ & $45.8 \%$ & 134 & $31.4 \% * * *$ & $17.4 \% * * *$ \\
\hline \multicolumn{7}{|l|}{ Institutional tranches } \\
\hline Fraction of term loan B & 131 & $24.3 \%$ & $19.5 \%$ & 134 & $46.7 \% * * *$ & $56.4 \% * * *$ \\
\hline Fraction of term loan C & 131 & $18.9 \%$ & $0 \%$ & 134 & $7.1 \% * * *$ & $0 \%$ \\
\hline Fraction of term loan D & 131 & $0.6 \%$ & $0 \%$ & 134 & $6.0 \% * * *$ & $0 \%$ \\
\hline Total institutional tranches & 131 & $43.9 \%$ & $44.1 \%$ & 134 & $59.7 \% * * *$ & $74.2 \% * * *$ \\
\hline Fraction of other tranches & 131 & $11.9 \%$ & $0 \%$ & 134 & $8.9 \%$ & $0 \%$ \\
\hline \multicolumn{7}{|c|}{ Panel B: Lead Bank CDO Underwriting Activity } \\
\hline & \multicolumn{3}{|c|}{$1996-2003$} & \multicolumn{3}{|c|}{ 2004-June 2008} \\
\hline & $\mathrm{N}$ & Mean & Median & $\mathrm{N}$ & Mean & Median \\
\hline $\begin{array}{l}\text { \% of loans with a lead bank underwriting } \\
\text { CDOs }\end{array}$ & 129 & $58.6 \%$ & $100 \%$ & 133 & $89.0 \% * * *$ & $100 \%$ \\
\hline Total CDO underwriting (\$bn) & 129 & 2.9 & 1.5 & 133 & $34.5^{* * *}$ & $31.1^{* * *}$ \\
\hline Loan amount/CDO underwriting & 78 & $11.8 \%$ & $5.3 \%$ & 119 & $6.1 \% * * *$ & $2.2 \% * * *$ \\
\hline Lender CDO funding & 73 & $1.1 \%$ & $0.7 \%$ & 119 & $1.9 \% * * *$ & $1.8 \% * * *$ \\
\hline \multicolumn{7}{|c|}{ Panel C: Loan Spreads and Covenants } \\
\hline & \multicolumn{3}{|c|}{$1996-2003$} & \multicolumn{3}{|c|}{ 2004-June 2008} \\
\hline & $\mathrm{N}$ & Mean & Median & $\mathrm{N}$ & Mean & Median \\
\hline \multicolumn{7}{|l|}{ Pro rata tranches: } \\
\hline Revolver (bp) & 93 & 284.4 & 300 & 100 & $242.4^{* * *}$ & $225^{* * *}$ \\
\hline Term loan A (bp) & 56 & 295.3 & 300 & 12 & 279.4 & 288 \\
\hline \multicolumn{7}{|l|}{ Institutional tranches: } \\
\hline Term loan B (bp) & 68 & 339.7 & 350 & 87 & $271^{* * *}$ & $250^{* * *}$ \\
\hline$\%$ of covenant-lite loans & 131 & $0 \%$ & $0 \%$ & 134 & $21 \%^{* * *}$ & $0 \%$ \\
\hline
\end{tabular}


Table 7: Tobit Regressions of Fraction of Institutional Tranches on Lenders' CDO Underwriting Activity

The dependent variable is percentage of institutional tranches, calculated as all institutional term loans over total long-term borrowing amount of the LBO loan. $\log ($ Total CDO) is logarithm of all CDOs underwritten by all lead banks of the loan in the year the LBO deal is announced. $\log (C D O E x-B S C L O)$ excludes balance sheet CLOs and $\log (C D O E x-C L O / C B O)$ excludes alls CLOs and CBOs. Loan Amount is total long-term borrowing amount of the loan. LBO Deal Value is the transaction value of the LBO deal net of fees and expenses. Loan Maturity is valueweighted average maturity of all institutional tranches. Target EBIT is percentage of operating income as of firm's total assets in the year before the deal. Std. Dev. of Target EBIT is standard deviation of Target EBIT in the five years before the deal, and Industry Std. Dev. of EBIT is the median of the standard deviation of EBIT for firms in the same Fama-French 48 industry over five years before the deal. Number of Banks is the number of lead banks and Bank size is logarithm of average total assets of these banks. R-squared from a corresponding OLS regression is reported for each model. T-statistics are reported in the second row for each independent variable. ***, **, * indicates statistical significance at the $1 \%, 5 \%$, and $10 \%$ levels, respectively.

\begin{tabular}{|c|c|c|c|c|c|c|}
\hline & \multicolumn{6}{|c|}{ Percentage of Institutional Tranches } \\
\hline & (1) & (2) & (3) & (4) & (5) & (6) \\
\hline \multirow[t]{2}{*}{$\log ($ Total CDO) } & 1.79 & 1.72 & & & & \\
\hline & $2.74 * * *$ & $2.73 * * *$ & & & & \\
\hline \multirow[t]{2}{*}{$\log (C D O E x-B S C L O)$} & & & 1.85 & 1.72 & & \\
\hline & & & $2.81^{* * *}$ & $2.69 * * *$ & & \\
\hline \multirow[t]{2}{*}{$\log (C D O E x-C L O / C B O)$} & & & & & 1.59 & 1.62 \\
\hline & & & & & $2.33 * *$ & $2.46 * *$ \\
\hline \multirow[t]{2}{*}{ Loan Amount/LBO Deal Value } & -5.45 & -2.28 & -5.54 & -2.55 & -5.32 & -2.38 \\
\hline & $3.02^{* * *}$ & 1.30 & $3.07^{* * *}$ & 1.43 & $2.92 * * *$ & 1.34 \\
\hline \multirow{2}{*}{ Loan Maturity } & -0.19 & -0.04 & -0.18 & -0.04 & -0.18 & -0.03 \\
\hline & $1.76^{*}$ & 0.42 & $1.66^{*}$ & 0.38 & $1.70^{*}$ & 0.34 \\
\hline \multirow{2}{*}{ Loan Amount/EBIT } & 0.55 & 0.24 & 0.55 & 0.23 & 0.52 & 0.21 \\
\hline & $2.41^{* *}$ & 1.12 & $2.41^{* *}$ & 1.10 & $2.28 * *$ & 1.00 \\
\hline \multirow[t]{2}{*}{ Log(LBO Deal Value) } & 3.94 & 2.61 & 3.73 & 2.46 & 4.07 & 2.57 \\
\hline & $2.59 * *$ & $1.90^{*}$ & $2.42^{* *}$ & $1.76^{*}$ & $2.64 * * *$ & $1.84^{*}$ \\
\hline \multirow[t]{2}{*}{ Target EBIT } & -0.35 & -0.25 & -0.37 & -0.26 & -0.38 & -0.26 \\
\hline & 1.39 & 1.08 & 1.45 & 1.12 & 1.48 & 1.12 \\
\hline \multirow{2}{*}{ Std. Dev. of Target EBIT } & 0.66 & 0.87 & 0.66 & 0.88 & 0.66 & 0.89 \\
\hline & 1.10 & 1.62 & 1.10 & 1.62 & 1.09 & 1.65 \\
\hline \multirow[t]{2}{*}{ Industry Std. Dev. of EBIT } & 0.87 & 0.84 & 0.84 & 0.81 & 0.83 & 0.80 \\
\hline & $1.91 *$ & $2.06^{* *}$ & $1.84^{*}$ & $2.00^{* *}$ & $1.81^{*}$ & $1.97 *$ \\
\hline \multirow[t]{2}{*}{ Number of Banks } & 0.25 & -3.05 & 0.25 & -2.87 & 0.62 & -2.75 \\
\hline & 0.08 & 1.08 & 0.08 & 1.02 & 0.20 & 0.98 \\
\hline \multirow[t]{2}{*}{ Bank Size } & -0.14 & -1.17 & -0.28 & -1.19 & 0.19 & -1.03 \\
\hline & 0.08 & 0.71 & 0.16 & 0.72 & 0.11 & 0.62 \\
\hline Year dummy & No & Yes & No & Yes & No & Yes \\
\hline \multirow[t]{2}{*}{ Constant } & 40.58 & 26.94 & 43.31 & 33.17 & 37.57 & 30.50 \\
\hline & $1.90 *$ & 1.10 & $2.01 * *$ & 1.31 & $1.75^{*}$ & 1.21 \\
\hline Observations & 170 & 170 & 170 & 170 & 170 & 170 \\
\hline OLS R-squared & 0.32 & 0.47 & 0.33 & 0.47 & 0.32 & 0.47 \\
\hline
\end{tabular}


Table 8: Effect of Lenders' CDO Funding on Pricing and Covenants of Leveraged Loans

This table reports OLS regression of spreads on term loan B tranches in the first four models and marginal effects of probit regressions of the likelihood of having covenant-lite term loan B tranche in the last four models. Lender CDO Funding is bank's CDO underwriting amount as a percentage of bank assets, averaged across all lead banks. Loan Maturity is value-weighted average maturity of all term loan B tranches. Log(Loan Amount) is logarithm of the long-term borrowing amount of the loan. Loan Amount/EBIT is loan amount divided by operating income of the target in the year before the deal. Target EBIT is percentage of operating income as of target assets. Std. Dev. of Target EBIT is standard deviation of Target EBIT over the five years before the deal. Industry Std. Dev. of EBIT is median of time series standard deviation of EBIT for firms in the same Fama-French 48 industry in the five years before. Number of Banks is the number of lead arrangers of the loan, and Bank size is logarithm of average total assets of these banks. GDP Growth is annual seasonally adjusted percentage change of GDP in the year. Fed Funds Rate and Prime Rate are annual rates computed from average monthly federal funds rate and bank prime rate. Rating dummies indicate if the loan is rated at BB, B, or CCC. T-statistics are reported in the second row for each independent variable. ${ }^{* *}, * *, *$ indicates statistical significance at the $1 \%, 5 \%$, and $10 \%$ levels, respectively.

\begin{tabular}{|c|c|c|c|c|c|c|c|c|}
\hline & \multicolumn{4}{|c|}{ Regression on Spread on Term Loan B } & \multicolumn{4}{|c|}{ Probit on Covenant-Lite } \\
\hline & (1) & (2) & (3) & (4) & (5) & (6) & (7) & (8) \\
\hline Lender $C D O$ & -16.88 & -15.31 & -13.99 & -16.51 & 0.09 & 0.03 & 0.02 & 0.06 \\
\hline Funding & $2.88^{* * *}$ & $2.45^{* *}$ & $2.28 * *$ & $2.08 * *$ & $3.81^{* * *}$ & $3.46^{* * *}$ & $3.42^{* * *}$ & $2.46^{* *}$ \\
\hline \multirow[t]{2}{*}{ Log(Loan Amount) } & -14.02 & -14.03 & -7.93 & 18.44 & 0.09 & 0.01 & 0.01 & 0.03 \\
\hline & 0.90 & 0.80 & 0.45 & 0.47 & 1.87 & 0.93 & 0.93 & 0.55 \\
\hline \multirow[t]{2}{*}{ Loan Maturity } & -0.27 & -0.28 & -0.13 & -1.02 & 0.00 & 0.00 & 0.00 & 0.01 \\
\hline & 0.64 & 0.65 & 0.30 & 1.45 & $1.96^{* *}$ & $2.52 * *$ & $2.57 * *$ & $1.69 *$ \\
\hline \multirow[t]{2}{*}{ Loan Amount/EBIT } & -0.83 & -0.91 & -0.93 & -7.17 & 0.00 & 0.00 & 0.00 & 0.01 \\
\hline & 0.60 & 0.64 & 0.66 & 1.06 & 0.42 & 0.51 & 0.85 & 0.57 \\
\hline \multirow[t]{2}{*}{ Log(Target Assets) } & -6.01 & -3.29 & -9.88 & -28.05 & -0.06 & -0.01 & -0.01 & -0.03 \\
\hline & 0.39 & 0.20 & 0.60 & 0.75 & 1.27 & 1.07 & 0.96 & 0.47 \\
\hline \multirow[t]{2}{*}{ Target EBIT } & -0.06 & -0.49 & -0.62 & -1.91 & 0.00 & 0.00 & 0.00 & 0.00 \\
\hline & 0.05 & 0.35 & 0.46 & 0.74 & 1.05 & 0.14 & 0.00 & 0.24 \\
\hline \multirow{2}{*}{$\begin{array}{l}\text { Std. Dev. of Target } \\
\text { EBIT }\end{array}$} & -2.10 & -2.48 & -1.83 & -0.12 & 0.00 & 0.00 & 0.00 & 0.00 \\
\hline & 0.85 & 0.94 & 0.70 & 0.04 & 0.49 & 0.95 & 1.24 & 0.45 \\
\hline \multirow{2}{*}{$\begin{array}{l}\text { Industry Std. Dev. of } \\
\text { EBIT }\end{array}$} & 2.06 & 2.36 & 2.01 & 2.61 & -0.02 & 0.00 & 0.00 & 0.01 \\
\hline & 1.17 & 1.28 & 1.11 & 1.14 & $1.92 *$ & $2.37 * *$ & $2.43^{* *}$ & $2.39 * *$ \\
\hline \multirow[t]{2}{*}{ Number of Banks } & & 8.47 & 5.52 & 3.52 & & -0.01 & -0.01 & -0.04 \\
\hline & & 0.70 & 0.46 & 0.26 & & 0.78 & 1.20 & 1.52 \\
\hline \multirow[t]{2}{*}{ Bank Size } & & -16.98 & -21.28 & -43.96 & & 0.05 & 0.04 & 0.11 \\
\hline & & 1.52 & $1.91 *$ & $2.57 * *$ & & $2.71 * * *$ & $2.79 * * *$ & $2.11^{* *}$ \\
\hline \multirow[t]{2}{*}{ GDP Growth } & & & -17.63 & -4.92 & & & -0.01 & -0.02 \\
\hline & & & $1.94 *$ & 0.42 & & & 0.96 & 0.65 \\
\hline \multirow[t]{2}{*}{ Fed Funds Rate } & & & -775.76 & -553.46 & & & -0.22 & -0.21 \\
\hline & & & $2.38^{* *}$ & 1.39 & & & 1.22 & 0.38 \\
\hline \multirow[t]{2}{*}{ Prime Rate } & & & 765.16 & 554.68 & & & 0.22 & 0.19 \\
\hline & & & $2.36^{* *}$ & 1.39 & & & 1.20 & 0.35 \\
\hline Rating Dummy & No & No & No & Yes & No & No & No & Yes \\
\hline \multirow[t]{2}{*}{ Constant } & 475.23 & 676.07 & -1427.55 & -542.03 & & & & \\
\hline & $8.13^{* * *}$ & $4.63^{* * *}$ & 1.46 & 0.45 & & & & \\
\hline Observations & 142 & 131 & 131 & 99 & 147 & 136 & 136 & 101 \\
\hline R-squared & 0.23 & 0.22 & 0.27 & 0.30 & & & & \\
\hline
\end{tabular}




\section{Table 9: Use of Bank Loans in Financing LBO Deals}

This table shows the use of long-term bank loans in financing deal considerations. All loans sponsoring one deal are aggregated at the deal level. The sample consists of all the deals for which the amounts of bank loan borrowing are available, and is split into two subsamples based on the relative size of CDO funding for lead banks. Panel A splits the sample using Lender CDO Funding, i.e., bank's CDO underwriting amount as a percentage of bank assets, averaged across all lead banks. The sample is split in Panel B by lead banks' underwriting amount of CDO excluding CBO and CLO, scaled by bank assets. Total bank loans are separated into two categories. Contingent loans refer to revolvers and non-contingent loans include all other long-term tranches. Funding need is total consideration paid by the acquirer, including fees and expenses, and is collected from proxy filings. In 39 deals when funding needs are not available, transaction values, which exclude fees and expenses, are used instead. EBIT is the target operating income in the year before the announcement. Interest is total interest payment on the loans expected for the first year, and is estimated as the multiple of tranche amounts and expected interest rate, calculated as 6-month LIBOR at the effective date plus spreads. All the variables are winsorized at a 5\% level in the whole sample. When the mean/median is different for the two subsamples, the significance of the difference is denoted with asterisks. ***, **, * indicates statistical significance at the $1 \%, 5 \%$, and $10 \%$ levels, respectively.

\begin{tabular}{|c|c|c|c|c|c|c|}
\hline \multicolumn{7}{|c|}{ Panel A: Subsamples split by median of Lender CDO Funding } \\
\hline & \multicolumn{3}{|c|}{ Deals Below Median } & \multicolumn{3}{|c|}{ Deals Above Median } \\
\hline & $\mathrm{N}$ & Mean & Median & $\mathrm{N}$ & Mean & Median \\
\hline \multicolumn{7}{|l|}{ Non-Contingent Loans } \\
\hline Loan / funding need (\%) & 120 & 35.5 & 29.0 & 121 & $41.8^{*}$ & $38.8^{* * *}$ \\
\hline Loan / EBIT & 114 & 2.8 & 2.1 & 109 & $4.6^{* * *}$ & $4.3^{* * *}$ \\
\hline EBIT / interest & 86 & 4.7 & 3.8 & 98 & $3.6^{* *}$ & $2.8^{*}$ \\
\hline \multicolumn{7}{|l|}{ Contingent Loans } \\
\hline Loan / funding need (\%) & 120 & 27.2 & 23.7 & 121 & $18.3^{* * *}$ & $10.9 * * *$ \\
\hline Loan / EBIT & 114 & 2.2 & 1.7 & 109 & $1.6^{* *}$ & $1.3^{*}$ \\
\hline EBIT / interest & 86 & 8.1 & 5.5 & 98 & $12.4^{* * *}$ & $10.1^{* * *}$ \\
\hline \multicolumn{7}{|l|}{ Total Bank Loans } \\
\hline Loan / funding need (\%) & 120 & 64.8 & 57.1 & 121 & 60.7 & 54.6 \\
\hline Loan / EBIT & 114 & 5.1 & 4.6 & 109 & $6.3^{* * *}$ & $6.0^{* * *}$ \\
\hline EBIT / interest & 86 & 3.2 & 2.4 & 98 & $2.8^{*}$ & 2.1 \\
\hline \multicolumn{7}{|c|}{ Panel B: Subsamples split by median of Lender CDO Funding-Ex CLO/CBO } \\
\hline & \multicolumn{3}{|c|}{ Deals Below Median } & \multicolumn{3}{|c|}{ Deals Above Median } \\
\hline & $\mathrm{N}$ & Mean & Median & $\mathrm{N}$ & Mean & Median \\
\hline \multicolumn{7}{|l|}{ Non-Contingent Loans } \\
\hline Loan / funding need (\%) & 120 & 35.7 & 29.2 & 123 & $42.1^{*}$ & $39.3^{* * *}$ \\
\hline Loan / EBIT & 114 & 2.8 & 2.2 & 111 & $4.6^{* * *}$ & $4.2^{* * *}$ \\
\hline EBIT / interest & 86 & 4.8 & 4.0 & 100 & $3.6^{* * *}$ & $2.8^{* *}$ \\
\hline \multicolumn{7}{|l|}{ Contingent Loans } \\
\hline Loan / funding need (\%) & 120 & 28.0 & 25.8 & 123 & $18.5^{* * *}$ & $11.1^{* * *}$ \\
\hline Loan / EBIT & 114 & 2.3 & 1.7 & 111 & $1.6^{* * *}$ & $1.3^{*}$ \\
\hline EBIT / interest & 86 & 8.4 & 5.0 & 100 & $12.1^{* * *}$ & $10.1^{* * *}$ \\
\hline \multicolumn{7}{|l|}{ Total Bank Loans } \\
\hline Loan / funding need (\%) & 120 & 65.5 & 56.8 & 123 & 61.0 & 55.6 \\
\hline Loan / EBIT & 114 & 5.1 & 4.6 & 111 & $6.2^{* * *}$ & $5.7^{* * *}$ \\
\hline EBIT / interest & 86 & 3.1 & 2.3 & 100 & 2.8 & 2.4 \\
\hline
\end{tabular}




\section{Table 10: Regressions of Use of Bank Loans}

This table reports the regressions of use of bank loan financing in LBOs on lead banks' CDO funding. Non-contingent bank loans exclude revolvers from total bank loans. The first three independent variables reflect CDO funding of lead banks. Lender CDO Funding is lead bank's CDO underwriting amount as a percentage of bank assets, averaged across all lending banks. Lender CDO Funding-Ex BS CLO excludes underwriting of balance-sheet CLO, and Lender CDO Funding-Ex CLO/CBO excludes underwriting of CLO and CBO. Target EBIT is target's operating income scaled by its total assets. Market-to-Book is the sum of market equity and total debt divided by total assets. Tangible Asset is calculated as property, plant and equipment divided by total assets. Book Leverage is longterm and short-term debt over total assets. Std. Dev. of Target EBIT is standard deviation of Target EBIT in the five years before the deal. Industry EBIT is the median operating income over assets for firms within the same Fama-French 48 industry in the year before the announcement, and Industry Std. Dev. of EBIT is median of the standard deviation of operating income relative to assets for firms in the same industry over five years before the deal. Absolute values of tstatistics are reported in the second row for each independent variable. ${ }^{* * *}, * *, *$ indicates statistical significance at the $1 \%, 5 \%$, and $10 \%$ levels, respectively. 


\begin{tabular}{|c|c|c|c|c|c|c|c|c|c|c|}
\hline & \multicolumn{6}{|c|}{ Non-Contingent Bank Loan } & \multicolumn{4}{|c|}{ Total Bank Loan } \\
\hline & \multicolumn{3}{|c|}{ Loan/EBIT } & \multicolumn{3}{|c|}{ EBIT/Interest } & \multicolumn{2}{|c|}{ Loan/EBIT } & \multicolumn{2}{|c|}{ EBIT/Interest } \\
\hline & $(1)$ & $(2)$ & (3) & (4) & (5) & (6) & $(7)$ & (8) & $(9)$ & $(10)$ \\
\hline Lender CDO Funding & $\begin{array}{l}0.59 \\
3.35^{* * *}\end{array}$ & & & $\begin{array}{l}-0.45 \\
1.86^{*}\end{array}$ & & & & & & \\
\hline $\begin{array}{l}\text { Lender CDO Funding- } \\
\quad \text { Ex BS CLO }\end{array}$ & & $\begin{array}{l}0.69 \\
3.73^{* * *}\end{array}$ & & & $\begin{array}{l}-0.47 \\
1.91^{*}\end{array}$ & & $\begin{array}{l}0.57 \\
2.86^{* * *}\end{array}$ & & $\begin{array}{l}-0.34 \\
2.37^{* *}\end{array}$ & \\
\hline $\begin{array}{l}\text { Lender CDO Funding- } \\
\quad E x \text { CLO/CBO }\end{array}$ & & & $\begin{array}{l}0.60 \\
2.32 * *\end{array}$ & & & $\begin{array}{l}-0.43 \\
1.16\end{array}$ & & $\begin{array}{l}0.56 \\
2.02 * *\end{array}$ & & $\begin{array}{l}-0.47 \\
2.18 * *\end{array}$ \\
\hline Log(Target Asset) & $\begin{array}{l}0.00 \\
0.01\end{array}$ & $\begin{array}{l}-0.03 \\
0.23\end{array}$ & $\begin{array}{l}0.09 \\
0.63\end{array}$ & $\begin{array}{l}0.01 \\
0.03\end{array}$ & $\begin{array}{l}0.01 \\
0.06\end{array}$ & $\begin{array}{l}-0.07 \\
0.35\end{array}$ & $\begin{array}{l}-0.29 \\
1.83^{*}\end{array}$ & $\begin{array}{l}-0.20 \\
1.29\end{array}$ & $\begin{array}{l}0.28 \\
2.41^{* *}\end{array}$ & $\begin{array}{l}0.25 \\
2.21^{* *}\end{array}$ \\
\hline Target EBIT & $\begin{array}{l}-8.24 \\
2.83^{* * *}\end{array}$ & $\begin{array}{l}-8.25 \\
2.86 * * *\end{array}$ & $\begin{array}{l}-7.93 \\
2.69 * * *\end{array}$ & $\begin{array}{l}13.70 \\
3.30 * * *\end{array}$ & $\begin{array}{l}13.62 \\
3.28 * * *\end{array}$ & $\begin{array}{l}13.43 \\
3.21^{* * *}\end{array}$ & $\begin{array}{l}-10.41 \\
3.32 * * *\end{array}$ & $\begin{array}{l}-10.23 \\
3.22 * * *\end{array}$ & $\begin{array}{l}8.25 \\
3.37 * * *\end{array}$ & $\begin{array}{l}8.33 \\
3.39 * * *\end{array}$ \\
\hline Market-to-Book & $\begin{array}{l}1.40 \\
3.82 * * *\end{array}$ & $\begin{array}{l}1.38 \\
3.77 * * *\end{array}$ & $\begin{array}{l}1.50 \\
4.04^{* * *}\end{array}$ & $\begin{array}{l}-1.34 \\
2.67 * * *\end{array}$ & $\begin{array}{l}-1.34 \\
2.67 * * *\end{array}$ & $\begin{array}{l}-1.42 \\
2.83^{* * *}\end{array}$ & $\begin{array}{l}1.53 \\
3.84 * * *\end{array}$ & $\begin{array}{l}1.63 \\
4.07^{* * *}\end{array}$ & $\begin{array}{l}-0.89 \\
3.01 * * *\end{array}$ & $\begin{array}{l}-0.94 \\
3.20 * * *\end{array}$ \\
\hline Book Leverage & $\begin{array}{l}-0.24 \\
0.35\end{array}$ & $\begin{array}{l}-0.19 \\
0.27\end{array}$ & $\begin{array}{l}-0.31 \\
0.44\end{array}$ & $\begin{array}{l}-0.22 \\
0.23\end{array}$ & $\begin{array}{l}-0.28 \\
0.30\end{array}$ & $\begin{array}{l}-0.18 \\
0.19\end{array}$ & $\begin{array}{l}0.22 \\
0.30\end{array}$ & $\begin{array}{l}0.12 \\
0.16\end{array}$ & $\begin{array}{l}-0.87 \\
1.57\end{array}$ & $\begin{array}{l}-0.79 \\
1.43\end{array}$ \\
\hline Std. Dev. of EBIT & $\begin{array}{l}-6.75 \\
1.16\end{array}$ & $\begin{array}{l}-6.68 \\
1.15\end{array}$ & $\begin{array}{l}-6.57 \\
1.11\end{array}$ & $\begin{array}{l}-11.22 \\
1.38\end{array}$ & $\begin{array}{l}-11.29 \\
1.39\end{array}$ & $\begin{array}{l}-11.44 \\
1.39\end{array}$ & $\begin{array}{l}-10.34 \\
1.64 *\end{array}$ & $\begin{array}{l}-10.16 \\
1.59\end{array}$ & $\begin{array}{l}-2.20 \\
0.46\end{array}$ & $\begin{array}{l}-2.54 \\
0.53\end{array}$ \\
\hline Growth of Sales & $\begin{array}{l}0.00 \\
0.25\end{array}$ & $\begin{array}{l}0.00 \\
0.25\end{array}$ & $\begin{array}{l}0.00 \\
0.18\end{array}$ & $\begin{array}{l}0.00 \\
0.69\end{array}$ & $\begin{array}{l}0.00 \\
0.70\end{array}$ & $\begin{array}{l}0.00 \\
0.65\end{array}$ & $\begin{array}{l}0.00 \\
0.25\end{array}$ & $\begin{array}{l}0.00 \\
0.19\end{array}$ & $\begin{array}{l}0.00 \\
0.94\end{array}$ & $\begin{array}{l}0.00 \\
0.86\end{array}$ \\
\hline Tangible Asset & $\begin{array}{l}0.51 \\
1.09\end{array}$ & $\begin{array}{l}0.52 \\
1.12\end{array}$ & $\begin{array}{l}0.45 \\
0.93\end{array}$ & $\begin{array}{l}-0.72 \\
1.13\end{array}$ & $\begin{array}{l}-0.72 \\
1.13\end{array}$ & $\begin{array}{l}-0.66 \\
1.04\end{array}$ & $\begin{array}{l}-0.09 \\
0.18\end{array}$ & $\begin{array}{l}-0.15 \\
0.30\end{array}$ & $\begin{array}{l}-0.22 \\
0.59\end{array}$ & $\begin{array}{l}-0.19 \\
0.52\end{array}$ \\
\hline Industry EBIT & $\begin{array}{l}1.15 \\
0.23\end{array}$ & $\begin{array}{l}1.18 \\
0.23\end{array}$ & $\begin{array}{l}0.51 \\
0.10\end{array}$ & $\begin{array}{l}-11.27 \\
1.71^{*}\end{array}$ & $\begin{array}{l}-11.07 \\
1.69 *\end{array}$ & $\begin{array}{l}-10.56 \\
1.60\end{array}$ & $\begin{array}{l}2.33 \\
0.43\end{array}$ & $\begin{array}{l}1.76 \\
0.32\end{array}$ & $\begin{array}{l}-0.62 \\
0.16\end{array}$ & $\begin{array}{l}-0.32 \\
0.08\end{array}$ \\
\hline $\begin{array}{l}\text { Industry Std. Dev. of } \\
\quad \text { EBIT }\end{array}$ & $\begin{array}{l}7.02 \\
0.93\end{array}$ & $\begin{array}{l}6.61 \\
0.88\end{array}$ & $\begin{array}{l}5.85 \\
0.76\end{array}$ & $\begin{array}{l}-16.30 \\
1.64^{*}\end{array}$ & $\begin{array}{l}-15.87 \\
1.60\end{array}$ & $\begin{array}{l}-15.21 \\
1.52\end{array}$ & $\begin{array}{l}4.14 \\
0.51\end{array}$ & $\begin{array}{l}3.36 \\
0.40\end{array}$ & $\begin{array}{l}-4.03 \\
0.69\end{array}$ & $\begin{array}{l}-3.29 \\
0.56\end{array}$ \\
\hline Constant & $\begin{array}{l}2.15 \\
1.67^{*}\end{array}$ & $\begin{array}{l}2.32 \\
1.81^{*}\end{array}$ & $\begin{array}{l}1.88 \\
1.45\end{array}$ & $\begin{array}{l}7.09 \\
4.08 * * *\end{array}$ & $\begin{array}{l}7.03 \\
4.04 * * *\end{array}$ & $\begin{array}{l}7.30 \\
4.18 * * *\end{array}$ & $\begin{array}{l}6.51 \\
4.68 * * *\end{array}$ & $\begin{array}{l}6.20 \\
4.44 * * *\end{array}$ & $\begin{array}{l}2.30 \\
2.24 * *\end{array}$ & $\begin{array}{l}2.40 \\
2.34^{* *}\end{array}$ \\
\hline $\begin{array}{l}\text { Observations } \\
\text { R-squared }\end{array}$ & $\begin{array}{l}222 \\
0.16\end{array}$ & $\begin{array}{l}222 \\
0.17\end{array}$ & $\begin{array}{l}222 \\
0.14\end{array}$ & $\begin{array}{l}184 \\
0.13\end{array}$ & $\begin{array}{l}184 \\
0.13\end{array}$ & $\begin{array}{l}184 \\
0.12\end{array}$ & $\begin{array}{l}222 \\
0.13\end{array}$ & $\begin{array}{l}222 \\
0.11\end{array}$ & $\begin{array}{l}184 \\
0.13\end{array}$ & $\begin{array}{l}184 \\
0.13\end{array}$ \\
\hline
\end{tabular}




\section{Table 11: Target Firm Characteristics and LBO Pricing}

The table describes target firms in the LBO sample, split into two subsamples at the median value of Lender CDO Funding. CDO-driven deals are deals borrowed from banks with Lender CDO Funding above the median, while non-CDO-driven deals are deals borrowed from banks with Lender CDO Funding below the median. Transaction values are total consideration paid by the acquirer, including payment to holders of common stock, preferred stock, option, warrants and debt retired, but excluding fees and expenses. All the target financial ratios are measures in the last year before the deal is announced, and over the five years before, for standard deviation or growth measures. Market Equity is stock price multiply the number of shares, and Market-to-Book is the sum of Market Equity and total debt divided by total assets. EBIT, CAPEX, and Tax Payment are calculated as operating income, capital expenditures, and income taxes over total assets, respectively. Tangible Asset is property, plant and equipment divided by total assets. Cash is cash and short-term investment divided by total assets. Book Leverage is total debt over total assets. Free Cash Flow is defined as (sales - cost of goods - expenses - change in working capital income taxes - dividend) / total assets. Std. Dev. of EBIT is standard deviation of EBIT in the five years before the deal. Std. Dev. of Growth in EBIT is standard deviation of changes in EBIT in the five years before the deal. Std. Dev. of Growth in Operating Margin is standard deviation of changes in operating margin, defined as operating income over sales, in the five years before the deal. Premium is the premium of the offered price over the stock price one month before the deal. FV/EBIT is calculated as the transaction value divided by operating income of the target in the year before the announcement and missing if EBIT is negative. EBIT/FV is operating income divided by transaction value, the inverse of FV/EBIT, but it is available for observations with negative EBIT. All of the three pricing measures are winsorized at a $5 \%$ level at the whole sample. The significance of the difference between the two subsamples is denoted with asterisks. ${ }^{* *},{ }^{* *}, *$ indicates statistical significance at the $1 \%, 5 \%$, and $10 \%$ levels, respectively.

\begin{tabular}{|c|c|c|c|c|c|c|}
\hline \multicolumn{7}{|c|}{ Panel A: Target Firm Characteristics } \\
\hline & \multicolumn{3}{|c|}{ Non-CDO-Driven Deals } & \multicolumn{3}{|c|}{ CDO-Driven Deals } \\
\hline & $\mathrm{N}$ & Mean & Median & $\mathrm{N}$ & Mean & Median \\
\hline Transaction Value (\$ml) & 151 & 762.8 & 129.4 & 154 & $3044.8^{* * *}$ & $922.5^{* * *}$ \\
\hline Total Asset (\$ml) & 148 & 824.9 & 155.7 & 150 & $2514.0^{* * *}$ & $743.7^{* * *}$ \\
\hline Market Equity (\$ml) & 144 & 585.5 & 86.7 & 148 & $2144.2^{* * *}$ & $574.0 * * *$ \\
\hline Negative EBIT & 154 & 0.15 & 0 & 154 & $0.01^{* * *}$ & 0 \\
\hline EBIT & 140 & 0.09 & 0.11 & 146 & $0.15^{* * *}$ & $0.14^{* * *}$ \\
\hline Market-to-Book & 148 & 1.06 & 0.91 & 150 & $1.23^{* *}$ & $1.07^{* * *}$ \\
\hline Growth of Asset & 153 & 0.26 & 0.07 & 154 & 0.22 & $0.13^{*}$ \\
\hline CAPEX & 144 & 0.06 & 0.04 & 149 & 0.06 & 0.04 \\
\hline Book Leverage & 148 & 0.37 & 0.40 & 150 & 0.40 & 0.41 \\
\hline Tangible Asset & 137 & 0.60 & 0.50 & 146 & 0.53 & 0.44 \\
\hline Free Cash Flow & 147 & 0.07 & 0.08 & 150 & $0.13^{* * *}$ & $0.11^{* * *}$ \\
\hline Tax Payment & 147 & 0.01 & 0.01 & 150 & $0.03 * * *$ & $0.02^{* * *}$ \\
\hline Std. Dev. of EBIT & 147 & 0.06 & 0.04 & 150 & $0.04 * * *$ & $0.03^{* * *}$ \\
\hline Std. Dev. of Growth in EBIT & 143 & 1.85 & 0.43 & 147 & $0.72 * *$ & $0.24^{* * *}$ \\
\hline $\begin{array}{l}\text { Std. Dev. of Growth in } \\
\text { Operating Margin }\end{array}$ & 143 & 1.77 & 0.28 & 147 & $0.48^{* *}$ & 0.17 \\
\hline \multicolumn{7}{|c|}{ Panel B: LBO Pricing } \\
\hline & \multicolumn{3}{|c|}{ Non-CDO-Driven Deals } & \multicolumn{3}{|c|}{ CDO-Driven Deals } \\
\hline & $\mathrm{N}$ & Mean & Median & $\mathrm{N}$ & Mean & Median \\
\hline Premium (\%) & 138 & 36.4 & 31.2 & 151 & $29.7 * *$ & $28.3^{*}$ \\
\hline FV/EBIT & 115 & 8.5 & 7.3 & 145 & 9.5 & $8.5^{* *}$ \\
\hline$E B I T / F V$ & 137 & 0.14 & 0.12 & 146 & 0.14 & 0.12 \\
\hline
\end{tabular}




\section{Table 12: Complete Financing Structure of LBO Deals}

This table reports financing structure of the 235 deals for which the complete financing structure can be identified. The information is collected from proxy filings and supplemented with DealScan for bank loans and SDC for junk bonds. Funding need, equity contribution, and asset-back finance are collected solely from proxy filings. The sample is split into two at the median value of Lender CDO Funding, defined as the lead banks' CDO underwriting amounts as a percentage of bank assets, averaged across all lead banks financing the deal. It is assigned zero if no bank loan is used. Funding need is the total consideration the acquirer needs to pay, including fees and expenses. Equity contribution includes investment from private equity sponsors and roll-over investors. The significance of the difference of the two subsamples is denoted with asterisks. ${ }^{* * *}, * *, *$ indicates statistical significance at the $1 \%, 5 \%$, and $10 \%$ levels, respectively.

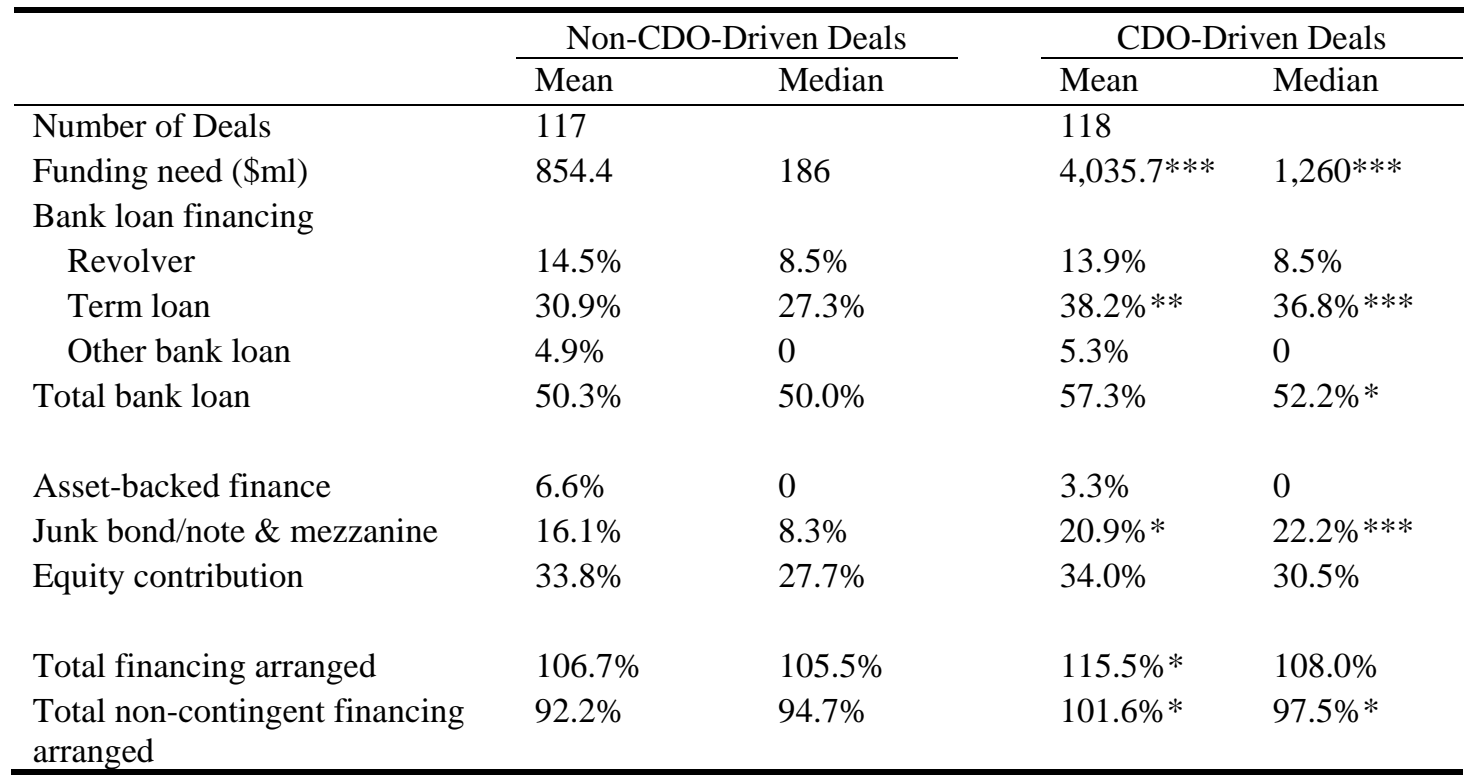




\section{Table 13: Effect of Lender CDO Funding on LBO Pricing}

This table reports the OLS regression of the measures of LBO pricing on banks' CDO Funding. Premium is the premium of the offered price over the stock price one month before the deal. FV/EBIT is calculated as the transaction value divided by operating income of the target in the year before the announcement and missing if EBIT is negative. EBIT/FV is operating income divided by transaction value. All of the three pricing measures are winsorized at a 5\% level. Lender CDO Funding is defined as lead banks' CDO underwriting amount as a percentage of bank assets, averaged across all lead banks financing the deal. It is assigned zero if no bank loan is identified. Industry EBIT is the median EBIT (scaled by total assets) for firms in the same Fama-French 48 industry as the target firm in the year before the LBO deal is announced. Std. Dev. of Industry EBIT is the median value of within-firm standard deviation of EBIT (scaled by total assets) over the five years before the deal across firms in the same Fama-French 48 industry. S\&P 500 Return and S\&P 500 P/E Ratio are return and P/E ratio of S\&P 500 index in the year when the deal is announced. All other variables are defined in Table 11. The second row of each variable reports t-statistics. ${ }^{* * *}, * *$, * indicates statistical significance at the $1 \%, 5 \%$, and $10 \%$ levels, respectively.

\begin{tabular}{|c|c|c|c|c|c|c|}
\hline & \multicolumn{2}{|c|}{ Premium } & \multicolumn{2}{|c|}{ FV/EBIT } & \multicolumn{2}{|c|}{ EBIT/FV } \\
\hline & $(1)$ & $(2)$ & $(3)$ & $(4)$ & (5) & $(6)$ \\
\hline \multirow[t]{2}{*}{ Lender CDO Funding } & -0.98 & -1.54 & 0.16 & 0.07 & -0.01 & -0.01 \\
\hline & 0.74 & 1.14 & 0.56 & 0.26 & 1.52 & 1.43 \\
\hline \multirow[t]{2}{*}{ Log(Target Assets) } & -2.57 & -2.95 & 0.76 & 0.33 & -0.01 & -0.01 \\
\hline & $2.54 * *$ & $2.96^{* * *}$ & $3.49 * * *$ & 1.56 & $3.36 * * *$ & $1.69 *$ \\
\hline \multirow[t]{2}{*}{ Market-to-Book } & -0.19 & 1.21 & 2.29 & 2.19 & -0.03 & -0.03 \\
\hline & 0.09 & 0.59 & $4.29 * * *$ & $4.08^{* * *}$ & $3.37 * * *$ & $3.93 * * *$ \\
\hline \multirow[t]{2}{*}{ Book Leverage } & 10.08 & 9.31 & -4.52 & -4.50 & 0.12 & 0.12 \\
\hline & $2.01 * *$ & $1.83^{*}$ & $4.36^{* * *}$ & $4.52^{* * *}$ & $6.29 * * *$ & $6.11^{* * *}$ \\
\hline \multirow[t]{2}{*}{ EBIT } & -19.83 & -22.91 & -5.75 & -3.56 & 0.15 & 0.14 \\
\hline & $1.83^{*}$ & $2.00 * *$ & $2.11 * *$ & 1.36 & $4.81^{* * *}$ & $4.36^{* * *}$ \\
\hline \multirow[t]{2}{*}{ Tax Payment } & 15.38 & 0.70 & 6.70 & 10.87 & 0.09 & 0.13 \\
\hline & 0.44 & 0.02 & 0.86 & 1.43 & 0.63 & 0.90 \\
\hline \multirow[t]{2}{*}{ Industry EBIT } & -43.64 & -36.83 & -14.26 & -8.27 & 0.15 & -0.03 \\
\hline & $1.87^{*}$ & 1.05 & $2.80^{* * *}$ & 1.12 & 1.63 & 0.20 \\
\hline \multirow[t]{2}{*}{ Std. Dev. of EBIT } & 45.33 & & 8.65 & & -0.38 & \\
\hline & 1.29 & & 1.00 & & $2.80 * * *$ & \\
\hline \multirow{2}{*}{$\begin{array}{l}\text { Std. Dev. of Growth in } \\
\text { Operating Margin }\end{array}$} & & -0.46 & & 0.31 & & -0.00 \\
\hline & & $1.67 *$ & & $2.00 * *$ & & $2.53 * *$ \\
\hline \multirow[t]{2}{*}{ Std. Dev. of Industry EBIT } & & 8.00 & & 9.55 & & -0.44 \\
\hline & & 0.14 & & 0.81 & & $1.92 *$ \\
\hline \multirow[t]{2}{*}{ S\&P500 Return } & & -25.49 & & & & \\
\hline & & $2.57 * *$ & & & & \\
\hline \multirow[t]{2}{*}{ S\&P500 P/E Ratio } & & & & -0.27 & & 0.00 \\
\hline & & & & $4.88 * *$ & & $2.43^{*}$ \\
\hline \multirow[t]{2}{*}{ Constant } & 49.87 & 55.90 & 4.99 & 12.26 & 0.202 & 0.14 \\
\hline & $6.88^{* * *}$ & $6.31^{* * *}$ & $3.30 * * *$ & $5.27 * * *$ & $7.06^{* * *}$ & $2.94 * * *$ \\
\hline Observations & 269 & 259 & 260 & 252 & 281 & 272 \\
\hline R-squared & 0.11 & 0.14 & 0.26 & 0.35 & 0.32 & 0.34 \\
\hline
\end{tabular}




\section{Figure 1: LBO Volume and CDO Issuance Amounts}

Total LBO volume is the aggregate transaction value of deals announced in each quarter for the sample of $345 \mathrm{LBO}$ deals from SDC satisfying the following criteria: the deal is announced between 1996 and the second quarter of 2008 and completed by July 28, 2008; the target is a U.S. company and publicly traded; transaction value is greater than $\$ 10$ million; at least $50 \%$ of common shares are acquired in the deal and the acquirers own $100 \%$ after. Transaction value of LBO is the total value of consideration paid by the acquirer, excluding fees and expenses. The CDO issuance amount aggregates the total CDOs issued worldwide. The CDO sample, from ABS Database, includes CDO issues rated by at least one major rating agency and under control of a trustee.

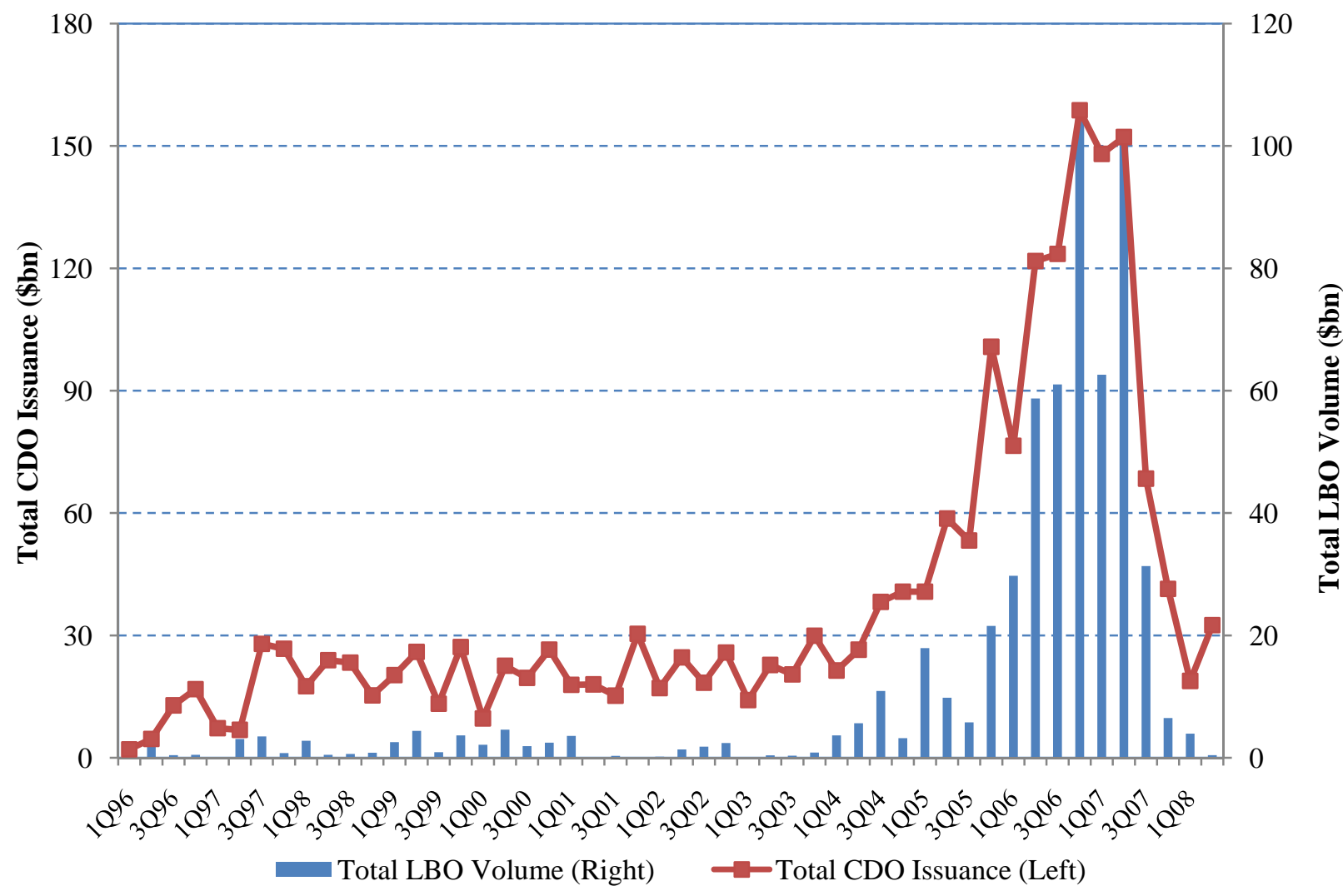




\section{Figure 2: Weekly Spreads on AAA-Rated CDO Tranches Backed by Different Collateral Assets}

The figure plots weekly average spreads on AAA-rated CDO tranches collateralized on high-yield loans, mezzanine structured products, and high-grade structured products. Data on secondary market average CDO spreads is from JP Morgan.

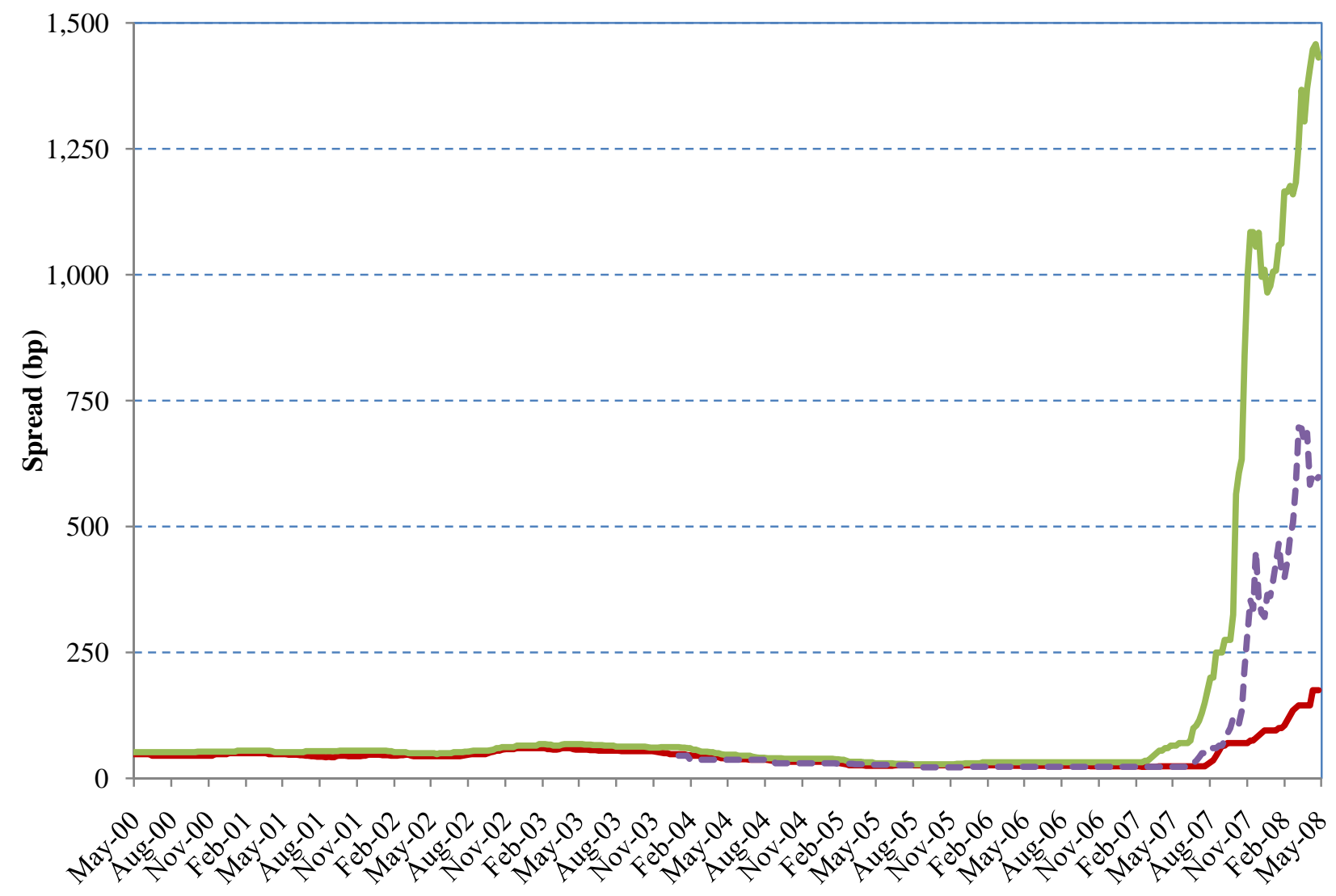

High Yield Loans $\longrightarrow$ Mezzanine Structured Products - - - High Grade Structured Products 


\section{Figure 3: Leveraged Loan Allocation and CLO Issuance Volume}

The figure shows quarterly amount of newly issued leveraged loans broken down by pro rata and institutional market allocation, and the issuance volume of collateralized loan obligations (CLOs). The leveraged loan volume is from S\&P's LCD and CLO volume is calculated using the ABS Database.

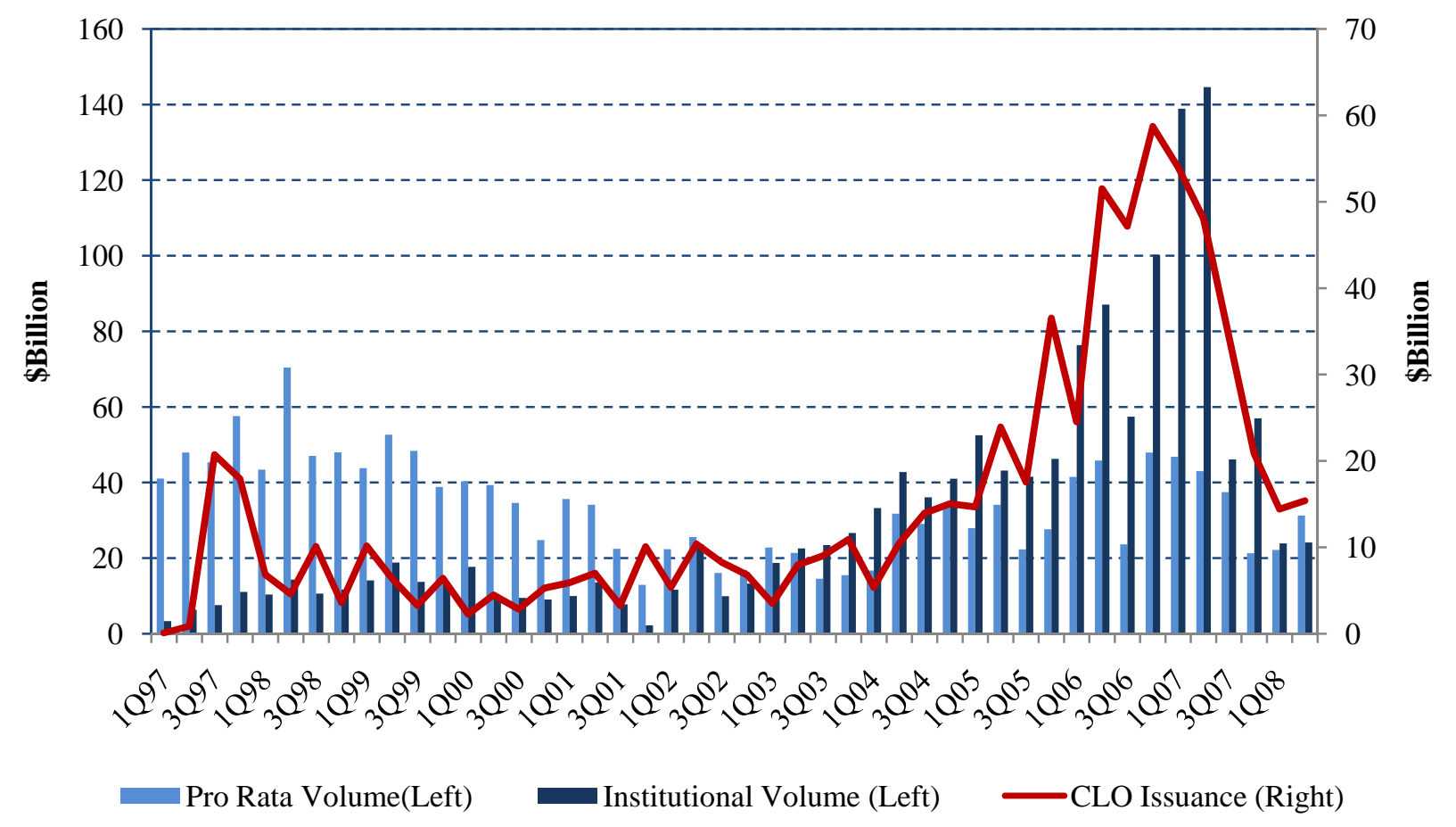




\section{Figure 4: LBO Loan Volume and Spreads on Institutional Tranches of Leveraged Loans}

The figure shows the aggregate amounts of bank loans financing the sample deals and average spreads of leveraged loans. The LBO loan sample includes 275 loans backing 241 deals. Short-term borrowing, such as bridge loans, is excluded. A loan is counted in the quarter when the LBO deal is announced. The institutional spreads are from LPC and shown for BB rated and B rated loans.

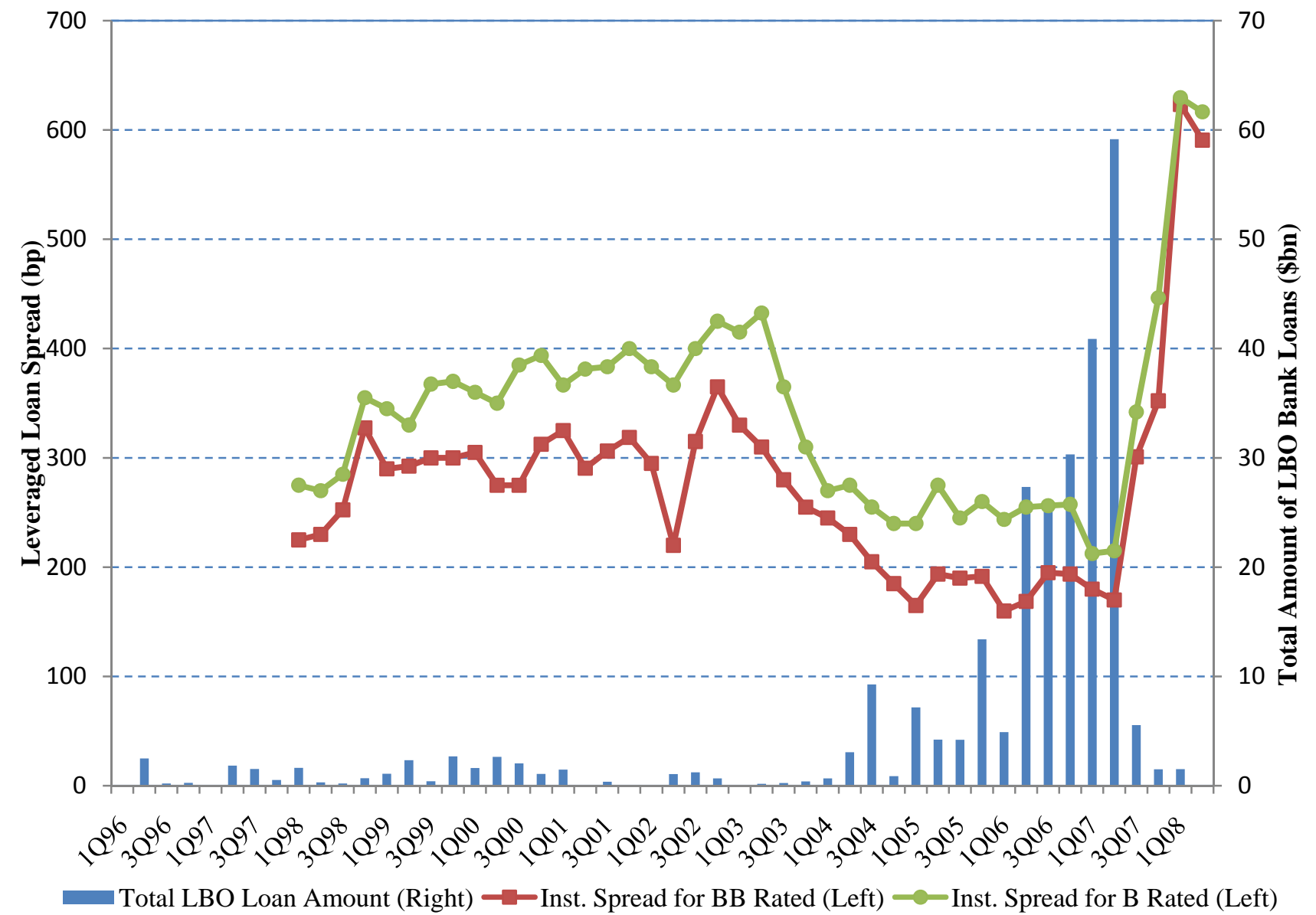

